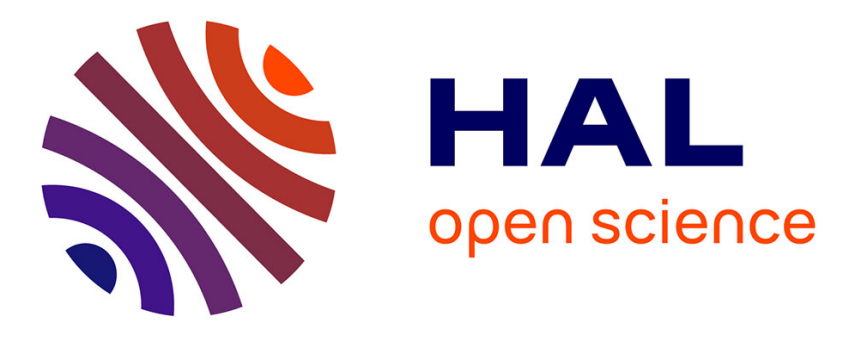

\title{
Glacial refugium versus range limit: Conservation genetics of Macoma Balthica, a key species in the Bay of Biscay (France)
}

Vanessa Becquet, Benoit Simon-Bouhet, Eric Pante, Herman Hummel, Pascale Garcia

\section{To cite this version:}

Vanessa Becquet, Benoit Simon-Bouhet, Eric Pante, Herman Hummel, Pascale Garcia. Glacial refugium versus range limit: Conservation genetics of Macoma Balthica, a key species in the Bay of Biscay (France). Journal of Experimental Marine Biology and Ecology, 2012, 432-433, pp.73-82. 10.1016/j.jembe.2012.07.008 . hal-00872186

\section{HAL Id: hal-00872186 https://hal.science/hal-00872186}

Submitted on 11 Oct 2013

HAL is a multi-disciplinary open access archive for the deposit and dissemination of scientific research documents, whether they are published or not. The documents may come from teaching and research institutions in France or abroad, or from public or private research centers.
L'archive ouverte pluridisciplinaire HAL, est destinée au dépôt et à la diffusion de documents scientifiques de niveau recherche, publiés ou non, émanant des établissements d'enseignement et de recherche français ou étrangers, des laboratoires publics ou privés. 
1 GLACIAL REFUGIUM VERSUS RANGE LIMIT: CONSERVATION GENETICS

2 OF MACOMA BALTHICA, A KEY SPECIES IN THE BAY OF BISCAY (FRANCE)

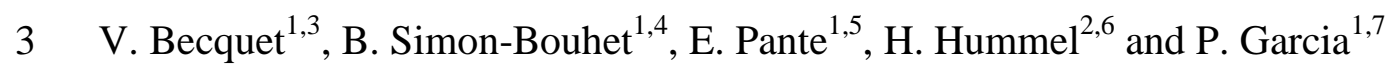

4 Corresponding author: V. Becquet

5 Tel: 033546507637

6 Fax: 033546458264

$7{ }^{1}$ Littoral Environnement et Sociétés, UMR 7266 CNRS, 2 rue Olympe de Gouges,

817000 La Rochelle, France

92 Centre for Estuarine and Marine Ecology, Netherlands Institute of Ecology,

10 Korringaweg 7, 4401 NT Yerseke, The Netherlands

$11 \quad{ }^{3}$ E-mail: vbecquet@univ-lr.fr

$12 \quad{ }^{4}$ E-mail: bsimonbo@univ-lr.fr

$13 \quad{ }^{5}$ E-mail: pante.eric@gmail.com

$14 \quad{ }^{6}$ E-mail: $\underline{\text { H.Hummel@ nioo.knaw.nl }}$

$15 \quad{ }^{7}$ E-mail: pgarciam@univ-lr.fr 
18 Abstract: The bivalve Macoma balthica (L.) is a key species of intertidal mudflats in

19 France and Europe. Its natural range has experienced a contraction along the European

20 coastline towards the northeast during the past five decades. This southern boundary

21 shift seems to be correlated with the increased sea surface temperature in the Bay of

22 Biscay (France), a major glacial refugium during the LGM (Last Glacial Maximum,

2318000 years ago). In this study, we used one mitochondrial marker (COI) and eight

24 nuclear microsatellite markers to reveal patterns consistent with populations that are

25 close to a glacial refugium. Meridional populations exhibit high genetic diversity,

26 contrary to what is expected from populations at the edge of a species range. In

27 addition, we highlight a barrier to gene flow in the Bay of Biscay populations, near

28 Brittany. So considering (i) the previously-reported sensitivity of $M$. balthica to

29 elevated temperatures, (ii) the genetic isolation of the southernmost populations, and

30 (iii) the importance of this species in the trophic web, the population ecology and

31 genetic structure of this species should be monitored in the context of global warming.

33 Keywords: Refuge zone, Global warming, Boundary shift, Macoma balthica,

34 Microsatellites, Hybrid zone. 
Populations located near the boundary of their distribution area theoretically present structural and genetic characteristics that may limit their adaptive capacity

38 (Eckert et al., 2008). Indeed, near the species range limit, populations are not at their optimum fitness level and most of the time exhibit a reduced growth rate (Brown et al., 1995; Thomas and Kunin, 1999). As a consequence they are often small, fragmented populations, vulnerable to genetic drift and exposed to the Allee effect and a reduced mutation rate (Courchamp et al., 1999; Alleaume-Benharira et al., 2006). Moreover, asymmetric gene flow from central populations toward those on the periphery restricts opportunities to develop local adaptations. This process, known as migration-selection balance, results in chronic maladaptation (Ronce and Kirkpatrick, 2001; Bolnick et al., 2008). Furthermore, environmental changes associated with supposedly low genetic diversity in populations close to the species range limit might increase the risk of extinction for such populations (Lawton, 1993; Vucetich and Wayte, 2003). The dynamic equilibrium between extinction and recolonization in these areas is more fragile, and renewal of populations more difficult (Lande et al., 2003). Under these conditions, the rate of environmental change is of direct importance because it is the main limitation to the development of an adaptive process.

In recent decades, the anthropogenic pressures applied to natural populations have dramatically increased (Vitousek et al., 1997; Walker and Kendrick, 1998), accelerating habitat fragmentation, change of species range and maladaptation. Moreover, during the last 30 years these effects have been accelerated by global warming (Bell and Collins, 2008) and are thus too recent and too fast for adaptation to have occurred. Indeed, stressors related to human activities (e.g. pollution, loss and fragmentation of habitat, release of invasive species) that lead to an interruption of connectivity within and between populations are synergistic with the increase in 
61 temperature (Gordon, 1998; Schroter et al., 2005). Thus, between 1906 and 2005, the

62 mean temperature of the earth surface increased by $0.74{ }^{\circ} \mathrm{C}$, partially due to the 63 greenhouse effect (GIEC, 2007), and in the marine environment the average temperature of surface waters increased by $0.23{ }^{\circ} \mathrm{C}$ per decade between 1977 and 2007 in the North East Atlantic (elevation of the surface water temperature in the Bay of Biscay in France, Goikoetxea et al., 2009). Parmesan and Yohe (2003) showed that, for more than 400 species, this phenomenon resulted in a shift in the distribution range coherent with the expected response to global warming: shifts of species range towards the pole, higher altitudes for terrestrial species or greater depths for aquatic species (see also Dulvy et al., 2008; Wethey and Woodin, 2008). The response to such environmental pressures in populations located near their range limit is not generally known (Walther et al., 2002) but the consequences of species range shifts on the functioning and structure of ecosystems might be serious, particularly when key species are concerned.

As an example, the Baltic clam, Macoma balthica (Linnaeus, 1758) (Bivalvia: Tellinidae), is an infaunal tellinid bivalve commonly present in marine and estuarine soft-bottom habitats of the northern hemisphere. As an important prey for migratory birds (Piersma and Beukema, 1993), macro-invertebrates (Edjung and Bonsdorff, 1992) and fish (Mattila and Bonsdorff, 1998), M. balthica occupies an important place in the trophic webs of the European coasts (Philippart et al., 2003). It is usually found in tidal

81 and subtidal sandy and muddy bottoms to a maximal depth of $30 \mathrm{~m}$ (Scarlatto, 1981;

82 Hummel, 1985). In Europe, it is currently widely distributed from the eastern Pechora

83 Sea (northern range limit) in Russia (Hummel et al., 1997b) to the Gironde estuary 84 (southern range limit) in France (Bachelet, 1980). Nevertheless, during the past five decades, the natural range of $M$. balthica has undergone a significant shift towards the northeast (Hummel et al., 2000). Abundant along the Atlantic coasts of the Iberian 
87 Peninsula more than 40 years ago (Otero and Milan, 1970), it has now completely

88 disappeared from this area.

Several evolutionary studies with contradictory results have already been performed on M. balthica. Väinölä (2003) used allozymes to show the existence of two groups of populations, one large homogeneous NE Atlantic population (including the Norwegian Sea, the North Sea and the coasts of the British Isles), and one structured meta-population with a high genetic diversity and a large number of alleles in the northern part of the natural range of the species (the Pacific ocean, the Baltic Sea and the White Sea). These two groups are supposedly two subspecies coexisting in Europe: the Pacific lineage $M$. balthica balthica and the Atlantic lineage $M$. balthica rubra (Väinölä, 2003). Mitochondrial markers confirmed these results (Luttikhuisen et al., 2003; Nikula et al., 2008) but also revealed a very specific mitochondrial pattern in the southernmost population of M. balthica (i.e. Gironde estuary, France), with haplotypes that are quite divergent from the other European and Pacific populations. In contrast, Hummel et al. (1995, 1997b) and Strelkov et al. (2007) did not find any isolation of

102 French Atlantic populations (including the Gironde and the Loire estuary) from other 103 populations using allozymes. The French populations were indeed similar to the

104 Norwegian Sea and western Barents Sea populations.

Thus, depending on the genetic markers used, studies have revealed two contrasting patterns for the populations in the Bay of Biscay: either (i) no differentiation

107 from the northern populations and a low genetic diversity, which is to be expected for 108 populations located near the species range limit, or (ii) a significant differentiation and 109 divergence from the northern populations. The Bay of Biscay represents the current

110 southern range limit of $M$. balthica but it was also one of the four major Pleistocene 111 refuges in Europe during the Last Glacial Maximum (LGM) 18,000 years ago (Gómez 112 and Lunt, 2007). As the ice retreated, populations recolonized northward by successive 
113 founder-events (Hewitt, 1999). These populations might have come into secondary

114 contact with Pacific populations recolonizing the Atlantic coasts from the North. In

115 these circumstances, genetic diversity is expected to decrease from the refuge zone

116 populations to the newly established populations (Petit et al., 2003).

117 From a conservation standpoint and given the theoretical vulnerability of

118 populations at the range limit, it is therefore of importance to have a proper description

119 of their precise distribution, genetic diversity and structure to infer their potential for

120 adaptation under shifting selective environments (e.g., climate change, anthropogenic

121 pressure; Moritz, 1994; Crandall et al., 2000). In this context, we conducted a

122 mitochondrial analysis of 12 populations sampled along the French coastline and 6

123 populations sampled in the North Sea, the English Channel and the North Atlantic

124 Ocean to assess historical processes. Contemporary features such as recent demographic

125 history and gene flow were investigated using a set of newly-developed microsatellite 126 markers (Becquet et al., 2009) with an emphasis on populations located at the edge of

127 the current natural range of M. balthica.

\section{2. MATERIALS AND METHODS}

$130 \quad 2.1$ Sampling

Adult specimens of $M$. balthica were collected between 2003 and 2007 at

13218 locations ranging from the Gironde estuary (known southern limit) to the Barents

133 Sea (Murman population, see Fig. 1 and Table 1 for precise locations and sample sizes).

134 Specimens were stored at $-20{ }^{\circ} \mathrm{C}$ or in $95 \%$ ethanol.

1352.2 Mitochondrial COI sequencing of PCR products

Total DNA was extracted from less than $15 \mathrm{mg}$ of muscle using the

137 Dneasy $^{\mathrm{TM}}$ Tissue Kit (Qiagen, Germany). Amplifications of a COI gene fragment 
138 (Cytochrome Oxidase Subunit 1) were performed using the set of primers described in

139 Luttikhuizen et al. (2003). Amplifications were carried out in a total volume of $50 \mu \mathrm{L}$

140 consisting of $1 \mathrm{X}$ PCR buffer, $1.85 \mathrm{mM} \mathrm{MgCl}_{2}, 125 \mu \mathrm{M}$ dNTPs, $0.25 \mu \mathrm{M}$ of each

141 primer, $1.6 \mathrm{U}$ of Taq DNA polymerase (Red Hot ${ }^{\circledR} T A Q$ DNA Polymerase, Abgène)

142 and about $10 \mathrm{ng}$ of template DNA. A MJResearch PTC 100 Thermal Cycler was used

143 with the following cycling profile: $3 \mathrm{~min}$ of initial denaturation at $95{ }^{\circ} \mathrm{C}$, followed by 35

144 cycles of denaturation at $95{ }^{\circ} \mathrm{C}$ for $45 \mathrm{~s}$, annealing at $60{ }^{\circ} \mathrm{C}$ for $60 \mathrm{~s}$ and extension at 72

$145{ }^{\circ} \mathrm{C}$ for $90 \mathrm{~s}$. A final extension step was carried out for $5 \mathrm{~min}$ at $72{ }^{\circ} \mathrm{C}$. Double-stranded

146 PCR products were cleaned using MultiScreen-PCR MANU03010 plates (Millipore).

147 The sequencing was performed by the Genoscreen corporation (Campus Pasteur - 1 rue

148 du Professeur Calmette - 59000 Lille - France) using an ABI PRISM® 3730 XL

149 automated DNA Sequencer (Perkin-Elmer Applied Biosystems, Foster City, CA).

150 Sequence data were aligned using Clustal W (Thompson et al., 1994) and ambiguities

151 were manually checked, comparing each sequence with its complementary fragment

152 using BioEdit (Hall, 1999).

$153 \quad 2.3$ Microsatellite amplification and genotyping

154 PCR amplifications of 8 microsatellite loci were conducted using the

155 primers described in Becquet et al. (2009). The protocol for DNA amplification

156 consisted in a touch-down PCR procedure: 3 min of an initial denaturation step at $95{ }^{\circ} \mathrm{C}$

157 followed by 10 cycles of denaturation at $95{ }^{\circ} \mathrm{C}$ for $45 \mathrm{~s}$, annealing at temperatures

158 decreasing by $1{ }^{\circ} \mathrm{C}$ per cycle from $\mathrm{T}_{\text {initial }}$ to $\mathrm{T}_{\text {annealing }}\left(\mathrm{T}_{\text {initial }}\right.$ varied between $68^{\circ} \mathrm{C}$ and 62

$159{ }^{\circ} \mathrm{C}$ depending on primers, Becquet et al., 2009) for $45 \mathrm{~s}$ and extension at $72{ }^{\circ} \mathrm{C}$ for $45 \mathrm{~s}$,

160 followed by 30 cycles at $95{ }^{\circ} \mathrm{C}$ for $45 \mathrm{~s}$, annealing at a final $\mathrm{T}_{\text {annealing }}$ for $45 \mathrm{~s}$ and 161 extension at $72{ }^{\circ} \mathrm{C}$ for $45 \mathrm{~s}$. A final extension step was carried out for 7 min at $72{ }^{\circ} \mathrm{C}$.

162 The PCR products were screened on $6.5 \%$ polyacrylamide gels using a Li-Cor NEN

163 Global IR2 DNA sequencer. Allele sizes were determined using a known DNA 
164 sequence with SAGA-GT software (v. 3.1: Automated microsatellite Analysis Software,

165 LI-COR Biosciences).

$1662.4 \mathrm{COI}$ sequence analyses

The haplotype number $H$, haplotype diversity $H_{d}$ (Nei, 1987), the number of

168 polymorphic sites $S$, and nucleotide diversity $\pi$ (i.e. average number of nucleotide

169 differences between pairs of sequences) were calculated for each population using the

170 DnaSP v.5 software (Librado and Rozas, 2009). In order to test the assumption that

171 populations at the range limit are less diversified than core populations, we defined two

172 sets of populations separated by Finistère (Brittany, Fig. 1): the 9 southernmost

173 locations were labelled as the 'Bay of Biscay' set (populations 1 to 9, Table 1) and the

174 remaining 9 sampling sites were labelled as the 'Core populations' set (populations 10

175 to 18 , Table 1). We examined the genetic structure of the overall and regional

176 population by performing an analysis of molecular variance (AMOVA, Excoffier et al.,

177 1992) as implemented in ARLEQUIN v.3.11. (Excoffier et al., 2005). Fixation indices

178 (Wright, 1951) analogous to the $F_{\mathrm{ST}}, F_{\mathrm{CT}}$ and $F_{\mathrm{SC}}$ parameters, were calculated to

179 analyze genetic differentiation between populations over the whole study area $\left(\Phi_{\mathrm{ST}}\right)$,

180 among groups of populations within the species range $\left(\Phi_{\mathrm{CT}}\right)$ and among populations

181 within groups $\left(\Phi_{\mathrm{SC}}\right)$ as defined in Excoffier et al. (1992). $\Phi$-statistics take into account

182 both haplotype frequencies and the molecular distances between haplotypes. Statistical

183 significance of the $\Phi$ indices was tested using a non-parametric permutation procedure

184 implemented in ARLEQUIN v.3.11. Moreover, one-sided tests to compare mean

185 haplotype numbers of the two sets and mean nucleotide diversities were performed in $\mathrm{R}$

186 v. 2.11.1 (R Development Core Team, 2010) using either the Student $t$-test or the

187 Wilcoxon test when parametric assumptions were not met.

Phylogenetic analyses at the intra-specific level were performed with the

189 Network software v. 4.0.0.0 (Bandelt et al., 1999) that builds haplotypic networks based 
190 on the median-joining algorithm (Cassens et al., 2003). This process combines both

191 minimum spanning trees and maximum parsimony approaches to simplify the complex

192 branching pattern and represent all the most parsimonious intra-specific phylogenies.

193 Such networks describe the evolutionary relationships (based on mutational events)

194 between the different haplotypes observed over the whole dataset. Finally, for each

195 population we calculated the D parameter defined by Tajima (1989) and estimated the

196 significance of deviations from zero in DNAsp v.5 (Librado and Rozas, 2009).

197 Geneland v. 4.0 (Guillot et al., 2005a, 2005b, 2012) was used to infer spatial population

198 structure. Geneland incorporates geographical information as a weak prior, with the

199 assumption that most populations exhibit some degree of spatial structuring, and that

200 the joint probability of any two individuals belonging to the same population decreases

201 with the geographical distance between them. For each run, the number of groups (K) at

202 Hardy-Weinberg equilibrium is assessed using maximum-likelihood estimations. Then,

$203 \mathrm{~K}$ is fixed at its most likely value and the posterior probability of belonging to each

204 class is computed for each individual of the dataset. Finally, maps of posterior 205 probabilities are generated. A total of 30 independent runs were computed in order to 206 check for the convergence of MCMC computations with the following parameters: 207 length of $\mathrm{MCMC}=150,000$ steps, thinning $=10$, maximum rate of Poisson process $=$ 208550 , maximum seed number for the Poisson-Voronoi tesselation $=1,650$.

2.5 Microsatellite analyses

212 Pairwise linkage disequilibrium among loci was tested using GENEPOP version 4.0.10

213 (Rousset, 2008), and significance levels were evaluated using a Markov-chain

214 randomization procedure (MCMC) with 10,000 dememorization steps, 5,000 batches 215 and 10,000 iterations per batch. The number of alleles per population and locus $\left(\mathrm{N}_{\text {all }}\right)$ 
216 and the observed $\left(\mathrm{H}_{\mathrm{o}}\right)$ and expected $\left(\mathrm{H}_{\mathrm{e}}\right)$ heterozygoties under Hardy-Weinberg

217 equilibrium were calculated using Genetix v. 4.05.2. (Belkhir et al., 1996-2004). Allelic

218 richness $\left(\mathrm{R}_{\text {all }}\right)$ was computed using FSTAT v. 2.9.3.2 (Goudet, 2002) to account for the

219 differences in sampling sizes across populations. Mean and overall $\mathrm{N}_{\text {all }}, \mathrm{R}_{\mathrm{all}}, \mathrm{H}_{\mathrm{o}}$ and $\mathrm{H}_{\mathrm{e}}$

220 were also computed for each set of populations (Bay of Biscay and Core population

221 sets). As for the mitochondrial dataset, one-sided Student or Wilcoxon tests were

222 performed in R v. 2.11.1 (R Development Core Team, 2010) to compare mean values

223 for each population set.

Population assignation tests were conducted using Geneclass v. 2.0 (Piry et al., 2004).

We followed the Bayesian approach of Rannala and Mountain (1997), and incorporated the exclusion-simulation significance test of Cornuet et al. (1999).

In addition to Geneland, two other Bayesian clustering programs, Structure and TESS, were used to infer structure among populations. Structure explores the number of populations in a dataset by optimizing Hardy-Weinberg equilibrium within putative groups, without taking geographical information into account. As Geneland, TESS uses geographical information in membership assignment. The three programs have different sensitivities to population structure and admixture levels (Chen et al., 2007; Guillot 2009; François and Durand 2010), and their comparative use allows weighing of the relative importance of geography.

236 Structure v. 2.3.2 (Pritchard et al., 2000; Falush et al., 2003, 2007; Hubisz et al., 2009)

237 was used to test 1 to 10 clusters. We ran 10 independent simulations for each $\mathrm{K}$ using 238 the admixture model, with a burnin period of 50,000 steps, and 200,000 post-burnin steps. The most likely number of clusters was inferred based on examination of $\ln$

240 P(D K $)$, as recommended by Pritchard et al. (2000). Scenarios with three and four 
241 clusters were equally likely; however, examination of population assignment plots

242 suggested that the presence of three clusters in our dataset was more probable. Geneland

243 analyses were performed as for the mitochondrial dataset (details above). TESS v. 2.3

244 (Durand et al., 2009) was run with the conditional auto-regressive (CAR) admixture

245 model, using 12,000 MCMC steps and a burnin period of 2,000 steps. Two to 10

246 clusters were tested, with 10 replicate runs of each $K_{\max }$. The spatial interaction

247 parameter was set to 0.6 and the degree of trend was linear. The most likely $\mathrm{K}_{\max }$ was

248 selected based on the Deviance Information Criterion (DIC), by minimizing its value

249 and its variance, and by examining plots of individual membership probabilities. The

250 most likely run among 10 replicates was then selected based on DIC.

\section{RESULTS}

3.1 Spatial population structuring

254 A 313-bp fragment of the COI gene was sequenced for 424 individuals sampled at 17 locations (Table 1, Fig.1). We identified 20 polymorphic sites defining 19 haplotypes (Genbank accession numbers: HM756170 to HM756189). The genealogical relationships among haplotypes are depicted in the minimum-spanning network presented in Fig. 2. The network is structured in three major clades organized around the 4 most frequent haplotypes (the combined frequencies for $\mathrm{H} 1$ to $\mathrm{H} 4$ was $94.7 \%$ ).

260 Three of these four haplotypes (H1 to H3) are separated by a single mutation, while haplotype H4 was found 3 mutations apart from the 3 others. The other 15 haplotypes were found at low frequencies and are equally spread around the 3 major clades. The

263 overall structure of the network is consistent with the geographic locations of sampling 264 sites: haplotypes $\mathrm{H} 1$ and $\mathrm{H} 2$ were found within the Bay of Biscay populations only, 265 haplotype H3 was found mostly in the English Channel and the North Sea, while the most divergent haplotype H4 is characteristic of the populations of Ireland and Murman 
267 (Fig. 2 and Fig. 3). For all sampling sites except WAD and IRE, Tajima's D did not

268 significantly deviate from the standard neutral model $(p>0.1$, Table 2$)$. We therefore

269 cannot reject the hypothesis of demographic equilibrium and selective neutrality (for the

270 mitochondrial locus studied) in most European populations.

271 The mitochondrial pairwise $F_{\text {ST }}$ estimates (Table 3) were found to be elevated and

272 highly significant when comparing populations from the Bay of Biscay set (populations

2731 to 9 ) with populations from the Core set (populations 10 to $18,0.325<F_{\mathrm{ST}}<0.938, p$

$274<0.001)$. This clustering was also significant according to the AMOVA results: the overall high genetic structure $\left(\Phi_{\mathrm{ST}}=0.613, p<0.0001\right)$ was mostly due to a large genetic differentiation between these 2 groups $\left(\Phi_{\mathrm{CT}}=0.587, p<0.0001\right)$ while the

277 genetic differentiation among populations within these groups appeared to be low ( $\Phi_{\mathrm{SC}}$ $278=0.0613, p<0.0001)$.

279 Assignation analyses with microsatellite markers revealed a high rate of self280 recruitment in all populations from the Bay of Biscay and the Core population sets. 281 Auto-assignation proportions ranged from $54 \%$ (Aiguillon) to $100 \%$ (Murman) with a 282 mean value of $70 \%$ (Fig. 4).

283 Spatial population clustering inferred from Structure, TESS and Geneland analyses led 284 to contrasting mitochondrial and nuclear patterns. Mitochondrial data, analysed using 285 Geneland, revealed significant clustering among (1) Bay of Biscay populations, (2) core 286 populations from Brittany to Germany, and (3) Ireland and Murman populations (Fig. 5, 287 Fig. S1). Microsatellite data, analysed with Geneland, Structure and TESS, could be 288 split into three clusters. Bay of Biscay populations were separated by the Loire estuary 289 and formed two groups ( $1^{\text {st }}$ group: populations $1-6 ; 2^{\text {nd }}$ group: populations $7-9 ; F_{\mathrm{ST}}=$ 290 0.044, Table S1). A second genetic break was detected at the tip of Finistère $\left(F_{\mathrm{ST}}\right.$ ranges 291 between 0.021 and 0.035 , Table S1). In addition, in a four-cluster scenario (data not 292 shown), TESS further split core populations into two strongly-admixed groups: (1) 
populations from Brittany to Germany, and (2) populations from Ireland and Murman.

3.2 Molecular diversity

296 Overall (except for the monomorphic population of Murman) the numbers of haplotypes

$297(\mathrm{H})$ and segregating sites $(\mathrm{S})$ ranged from 2 to $5($ mean $=3.35, \mathrm{sd}=1.32)$ and from 2 to 7

298 (mean $=3.71, \mathrm{sd}=1.65)$, respectively (Table 2$)$. The mean haplotype number (see Table

299 2) was significantly higher in the Bay of Biscay set than in the Core set (one-sided

300 Wilcoxon test, $W=55, p=0.033$ ). The same result was obtained for nucleotide

301 diversity (one-sided Wilcoxon test, $W=57, p=0.023$ ) with an even more striking

302 difference between the population sets: the mean nucleotide diversity within the Bay of

303 Biscay set $(\pi=0.03153 \pm 0.02646)$ was found to be more than ten fold greater than

304 within the Core set $(\pi=0.00275 \pm 0.00192$, Table 2$)$.

305 The multilocus genotype (8 microsatellite markers) was obtained for 545 individuals

306 collected at 18 sampling sites (Table 1). No linkage disequilibrium was detected

307 between loci (pairwise exact tests, $p>0.2)$. Overall, the mean number of alleles $\left(\mathrm{N}_{\mathrm{all}}\right)$

308 ranged from 6.62 (Bonne Anse) to 11.25 (Aytré) with a total of 20.87 over the whole

309 dataset (Table 2). Most of the differences observed across populations were due to

310 varying sample sizes since all allelic richness values $\left(\mathrm{R}_{\text {all }}\right)$ were similar, ranging from

3114.0295 (Seine) to 4.7716 (Aiguillon) (overall population mean and standard deviation $=$

$3124.39 \pm 0.23$ ). However, a highly significant difference was found when comparing

313 mean $\mathrm{R}_{\text {all }}$ values for both population sets (one-sided two-sample Student $t$-test, $t=$

$3145.933, d f=16, p=1.051 \mathrm{e}^{-5}$ ): a greater mean $\mathrm{R}_{\text {all }}$ value was found within the Bay of

315 Biscay set $\left(R_{\text {all }}=4.58 \pm 0.15\right)$ than within the Core set $\left(R_{\text {all }}=4.21 \pm 0.12\right.$, see also Fig. 316 6).

317 The same pattern was observed for both the observed $\left(\mathrm{H}_{\mathrm{o}}\right)$ and the expected $\left(\mathrm{H}_{\mathrm{s}}\right)$ 318 heterozygosities (see Fig. 7). While $\mathrm{H}_{\mathrm{o}}$ and $\mathrm{H}_{\mathrm{s}}$ showed little variation across the whole 
dataset (the mean and standard deviation across the 18 populations was $0.366 \pm 0.0425$ and $0.6325 \pm 0.0347$ for $H_{o}$ and $H_{s}$ respectively, Table 2), both indices were found to be significantly greater in the Bay of Biscay set than in the Core set $(t=2.513, d f=16, p=$ 0.012 for $\mathrm{H}_{\mathrm{o}}$ and $t=2.246, d f=16, p=0.020$ for $\mathrm{H}_{\mathrm{s}}$ ). Heterozygote deficiency was high for all populations (mean $F_{\text {IS }}$ value and standard deviation of $0.424 \pm 0.054$ ). The same levels of heterozygote deficiency were found in both sets (mean $F_{\text {IS }}$ and standard deviation $=0.4187 \pm 0.0491$ and $0.4305 \pm 0.0603$ for the Bay of Biscay set and for the Core set, respectively) and a two-sided Student $t$ test showed no difference between the set means $(t=0.457, d f=16, p=0.654)$.

\section{DISCUSSION}

\subsection{Genetic structure}

4.1.1 High gene flow at macro-scale

334 The first stage of development of $M$. balthica consists of a 2 to 5 week period of larval 335 pelagic life, during which larvae can be carried over long distances by ocean currents 336 before they settle (Beukema and De Vlas, 1989; Caddy, 1967; Drent, 2002). As a 337 consequence, in the absence of physical or genetic barriers, populations are supposed to 338 be highly connected by gene flow (Caley et al., 1996). However, the detection of first generation migrants with microsatellite markers showed the existence of a high self-

340 recruitment inside each population sampled along the coasts of Europe. This result is 341 congruent with those obtained with many marine benthic organisms for which evidence

342 of a high proportion of self-recruitment at local spatial scales has accumulated (Cowen 343 et al., 2000; Armsworth et al., 2001). Hence, a larval dispersion model tested on the 344 marine polychete Pectinaria korenii confirmed that a strong larval retention in a bay led 345 to self-recruitment (Ellien et al., 2000); marine ecologists have recently argued for a 
346 paradigm shift, advocating the preponderance of self-recruitment (Hellberg et al., 2002;

347 Swearer et al., 2002). Among the many parameters potentially involved in self-

348 recruitment, the literature emphasizes the importance of larval behaviour and mortality

349 as well as oceanographic features on the effective dispersal distance of marine species

350 (Kingsford et al., 2002; Siegel et al., 2003; Toonen and Tyre, 2007).

351 In spite of this high self-recruitment, the genetic structure analysis of natural

352 populations of $M$. balthica with a mitochondrial marker showed a high level of gene

353 flow at the European scale. Indeed, only 3 clades separated by a few mutations (1 to 3 )

354 were detected with mtDNA. However, the genetic structure analysis revealed a clear

355 gene flow rupture between the Bay of Biscay population set (i.e. populations 1 to 9) and

356 the core population set located in the North (Fig. 1) with a high genetic differentiation

357 (Table 3, $0.325<F_{\mathrm{ST}}<0.938$ ). This reproductive isolation between the Bay of Biscay

358 populations and the other European populations is in agreement with previous results

359 obtained by Luttikhuisen et al. (2003) and is probably due to the marine biogeographic

360 boundary located around Brittany. As underlined by Leppäkoski et al. (2002), the

361 effects of the Gulf Stream along the European coastline result in a strong biogeographic

362 barrier around Brittany for a variety of marine phyla, limiting species exchange between

363 the northern and southern areas. This gene flow rupture between populations located on

364 both sides of the tip of Brittany has already been established for several marine

365 invertebrate species, including Pecten maximus (Wilding et al., 1997), Mytilus sp.

366 (Bierne et al., 2003a), Crepidula fornicata (Dupont et al., 2003) and Pectinaria koreni

367 (Jolly et al., 2005).

369 4.1.2 Discordance between mitochondrial and nuclear genetic structure.

370 Within the Bay of Biscay, the genetic structure inferred from the results with the two

371 types of markers (mtDNA and nuclear) differed significantly. The mitochondrial 
structure revealed almost identical haplotype frequencies for all sampling sites within

373 the Bay of Biscay (high frequency of clade 1 haplotypes, very low frequency or absence

374 of clade 2 and 3 haplotypes, Fig. 1 and Fig. 3) with no significant pairwise

375 differentiation between populations (Table 3), a pattern confirmed with the Bayesian

376 analysis performed on mitochondrial data with Geneland. These results suggest that all

377 sampling sites in the area belong to a unique panmictic population. On the contrary, the

378 Bayesian simulations performed with microsatellite markers showed a strong and well

379 supported genetic break within the Bay of Biscay, focused on the Loire estuary (i.e.

380 between populations 6 and 7, Fig. 5). This gene flow rupture was not detected in

381 previous studies, probably because of the limited resolution of the markers used

382 (mitochondrial marker in Luttikhuisen et al. 2003 and Nikula et al. 2007 and allozymic

383 markers in Hummel et al. 1997b) and because of the low number of populations

384 sampled within the Bay of Biscay.

385 Local hydrodynamics during the larval stage might explain this genetic barrier within

386 the Bay of Biscay. Indeed, a postzygotic isolation might exist within the semi-closed

387 Bay of Marennes-Oléron and, on a wider scale, within the Pertuis Charentais area (i.e.

388 populations 1 to 6 ) where a $1300 \mathrm{~km}^{2}$ semi-closed area is delineated by two $30 \mathrm{~km}$-long

389 islands only a few kilometres apart. This assumption is supported by the high self-

390 recruitment detected in this study (Fig. 4). Larval retention might be reinforced for

391 populations 1 to 6 as waters from the Gironde and Loire estuaries rarely mix, leading to

392 the formation of eddies and up-wellings that favor larval retention (Lazure and Jegou,

393 1998). The incongruence between mitochondrial and nuclear data, however, would

394 suggest that this barrier is too recent to be detected with mitochondrial markers, which

395 tend to evolve more slowly that microsatellite ones (e.g. Brown et al., 1979; Estoup and

396 Angers, 1998). This hypothesis is unlikely, as the Loire estuary was already present in

397 the Pleistocene, when profound structuration of mitochondrial lineages occurred. 
398 The nuclear genetic differentiation inside the Bay of Biscay might also be the result of

399 divergent selection. Indeed, even if Tajima's D test failed to reveal selection, the

400 selection might occur at a contemporary scale. Moreover, the nine populations studied

401 here are impacted by contrasting environmental factors since the characteristics of the

402 water masses in this area are especially influenced by the Loire and Gironde estuaries.

403 The Loire estuary is known to be greatly affected by Polycylic Aromatic Hydrocarbon

404 (PAH) and polychlorobiphenyls (PCB, RNO, 2004b), while the Gironde estuary

405 (directly connected with the Charente estuary and Bay of Marennes Oleron, Boutier et

406 al., 2000) is heavily impacted by trace metals (e.g. $\mathrm{Cd}, \mathrm{Zn}, \mathrm{Cu}$, Grousset et al., 1999;

407 RNO, 2004b).

408 This contrasting pattern obtained with these different types of markers might be a

409 consequence of a genetic barrier to gene flow like those observed in transition zones

410 (Lemaire et al., 2005). During the Pleistocene, Pacific populations of $M$. balthica

411 colonized the Atlantic Ocean down to the Iberic coasts after the opening of the Bering

412 Strait (Väinölä, 2003). Throughout the Last Glacial Maximum (LGM, 18,000 years

413 ago), all the northern European coasts were covered by ice except for the Bay of Biscay

414 and the Spanish region, which is known to have been one of the four major temperate

415 refugia (Gómez and Lunt, 2007). After the LGM, natural populations of $M$. balthica in

416 this area became the source for the recolonization of northward sites (Austin et al.,

417 2004; Howes et al., 2006). Meanwhile, after the complete disappearance of the ice

418 sheets from northern Europe, migration began again from North to South. Thus, the

419 post-glacial recolonization of the northern European coasts occurred from two isolated

$420 \quad M$. balthica stocks via two distinct paths: (i) a South to North route from an Iberian

421 refugium and (ii) a North to South route from the Pacific Ocean; this migration led to a

422 secondary contact between differentiated populations. The existence of genetic

423 signatures typical of a hybrid zone (Barton and Hewitt, 1985) might be the consequence 
424 of the admixture of divergent $M$. balthica lineages in the Bay of Biscay. First, the

425 incongruence between mitochondrial and nuclear data is typical of transition zones

426 (Lemaire et al., 2005). A hybrid zone can emerge when two divergent lineages come 427 into secondary contact (Barton and Hewitt, 1985), which has previously been shown for

428 M. balthica (Väinölä, 2003; Luttikhuisen et al., 2003). Hybridization between distinct 429 mitochondrial lineages ( $M$. balthica balthica and $M$. balthica rubra) has indeed been 430 described in the Baltic (Nikula et al., 2007). In addition, biogeographic conditions among French sampling locations is conducive to the establishment of contact zones as semi-permeable hydrographic barriers may exist (e.g. Loire and Finistère), and a population density drop was observed around Finistère (pers. obs.). Finally, two closely

434 located hybrid zones have been well documented in the Bay of Biscay between Mytilus edulis and My. galloprovincialis (Bierne et al., 2002, 2003b).

4.2 Genetic diversity within peripheral populations

In the standard abundant-center model, species are expected to be at lower abundance at

440 the edge of the range than at the geographical centre, with populations becoming 441 progressively smaller, more fragmented and sparsely distributed (Lawton, 1993;

442 Vucetich and Waite, 2003). Genetic organization is thus affected in terms of diversity 443 and population structure. As an example, several studies showed that peripheral 444 populations exhibit low genetic diversity, greater genetic differentiation (structured 445 metapopulations), small effective population sizes and geographic isolation as 446 compared to more central populations (El Mousadik and Petit, 1996; Durka, 1999; 447 Bouzat and Johnson, 2004).

448 Contrary to these theoretical expectations (and to previous results based on isoenzymes 449 only, Hummel et al., 1997b) but according to expectations of a glacial refugium (Maggs 
et al., 2008), our study revealed a significantly higher genetic diversity in populations

451 from the Bay of Biscay than in the Core population set. Haplotype number, haplotype

452 and nucleotide diversities, observed and expected heterozygosities and allelic richness

453 all support this tendency (Table 2, Fig. 6, Fig. 7). Besides, despite a high overall

454 heterozygote deficiency $\left(F_{\mathrm{IS}}=0.4305\right)$ which was also observed for many marine

455 molluscs (Zouros and Foltz, 1984), the Bay of Biscay populations do not seem to be

456 affected by inbreeding, as confirmed by the high levels of genetic diversity in these

457 populations. This peculiar genetic pattern is thus more characteristic of a population

458 coming from a refuge zone (Gómez and Lunt, 2007; Maggs et al., 2008) than of a

459 population located at the range limit of a species. Hewitt (1999) clearly established that

460 a feature of temperate species (e.g. alder, beech, grasshoppers and newts) in southern

461 Europe was the presence of several distinct "geographical genomes" with a variety of

462 alleles. This pattern is present in southern populations of $M$. balthica, which exhibit two

463 of the four major haplotypes ( $\mathrm{H} 1$ and $\mathrm{H} 2$ ) found exclusively within the Bay of Biscay.

464 On the other hand, the haplotypes H3 and H4 were rarely found in the Bay of Biscay 465 populations but were the most frequent in every population from the Core set (except 466 for the strictly monomorphic population of Murman, Figs. 2 and 3). Likewise, the 467 higher nuclear diversity observed in the Bay of Biscay populations is mainly due to the 468 high number of private alleles (i.e. alleles sampled only once) found in these 469 populations. Regarding the loci mac40, mac10 and mac84, $44 \%, 47 \%$ and $69 \%$ of 470 these alleles were found only in the southernmost populations. These populations 471 exhibit a total of 42 rare and private alleles across 8 loci while Core-populations exhibit 472 only 19.

473 These results are consistent with a rapid northward expansion after the Last Glacial 474 Maximum from a refuge zone located either in Spain or in the Bay of Biscay, and might 475 be a reflection of cryptic populations. 
$477 \quad 4.3$ Implications for conservation

478 During the last 50 years the natural range $M$. balthica has undergone a strong northward 479 contraction, as observed in many other species (Koutsikopoulos et al., 1998; Parmesan 480 and Yohe, 2003). The populations currently located near the southern range limit of the 481 species (i.e. in the Bay of Biscay) present higher genetic diversity than populations 482 located in the North. However, the Bay of Biscay populations might be at risk because 483 of the strong barrier to gene flow around Brittany, isolating these populations from the center of the natural range.

485 The potential disappearance of $M$. balthica along the French Atlantic coasts may have 486 negative cascading effects on littoral ecosystems. As the favourite prey for many 487 shorebirds, fishes and macro-invertebrates (Piersma and Beukema, 1993; Edjung and 488 Bonsdorff, 1992; Mattila and Bonsdorff, 1998), M. balthica is a key species for 489 intertidal communities. The Pertuis Charentais area and southern Brittany (where 490 populations 1 to 9 were sampled) are known to be a major wintering area for the Black 491 Tailed Godwit Limosa limosa (Gill et al., 2007), a species that feeds almost exclusively 492 on $M$. balthica stocks on intertidal mudflats (Bocher P, Robin F, personal 493 communication). Indeed, Zwarts and Blomert (1992) highlighted the energetic 494 importance of $M$. balthica intake among a 5 species mix of bivalves in the diet of 495 another shorebird, Calidris canutus. Its disappearance could thus have a dramatic and

496 lasting impact on the whole ecosystem. As an illustration, the decreasing bivalve 497 recruitment observed in the Wadden Sea (confirmed by a positive and significant 498 Tajima's D value) led to a massive emigration, starvation and mortality of bivalve499 eating birds (Camphuysen et al., 2002).

501 In addition to the warming of surface waters in the North East Atlantic, many 
502 anthropogenic pressures might have accelerated the shift northward of range of $M$.

503 balthica. Pollution and habitat fragmentation induced by littoral industrialization are

504 two possible factors. Nevertheless, many studies have been conducted on the

505 performance of $M$. balthica in highly polluted sites (Szefer and Skwarzec, 1988;

506 Pempkowiak and Szefer, 1992; Pempkowiak et al., 1999). These showed that $M$.

507 balthica seemed to remain a major component of the macrozoobenthic communities in

508 heavily polluted environments when other species were declining or had disappeared

509 (Szaniawska et al., 1996).

510 In contrast, an increase in temperature is known to greatly affect the physiological

511 capacities of individuals, especially for organisms living at the low latitude margin of

512 their natural range (Hugues, 2000). A recent study on the metabolic and respiratory

513 rates of $M$. balthica (Jansen et al., 2007) revealed a zero plasticity to temperature for

514 populations close to the southern range limit. The author translocated a Gironde

515 population to the Bidasoa Bay (where $M$. balthica was present 50 years ago) and

516 observed rapid mortality. These results reinforced those published by Hummel et al.

517 (1998) showing limited ecophysiological performances for M. balthica populations at

518 the edge of its natural range.

519 The increase of surface waters temperature due to climate change is expected to affect

520 adult survival, dispersal abilities and pelagic larval duration (O'Connor et al., 2007,

521 Munday et al., 2008) and would potentially limit population connectivity (Cowen and

522 Sponaugle, 2009). Indeed, temperature will affect larval stage in two ways. First, it will

523 affect basal metabolism, growth, development and energetic costs for larvae, thus

524 modifying the pelagic larval duration (Shanks et al., 2003). Second, the increase in

525 temperature of water bodies encountered by pelagic larvae might be responsible for

526 current displacement (as well as eddies or up-wellings), potentially altering larval

527 transport, growth and survival (Meekan et al., 2003). This connectivity between sub- 
528 populations would potentially impact the population dynamics and structure and would

529 then have a major role in terms of conservation and species management (Cowen et al.,

530 2007).

531 CONCLUSION

532 We showed that $M$. balthica populations located near the species southern range limit

533 exhibited high genetic diversity, probably due to the secondary contact of two isolated

534 gene pools after the last glacial maximum. However, a high diversity at neutral loci is

535 not enough to guarantee the survival of a population, as suggested by the disappearance

536 of the southern French and Spanish populations during the last 50 years. The strong

537 barrier to gene flow isolating the Bay of Biscay populations from the central area of the

538 species range makes them even more vulnerable to environmental changes. A fine scale

539 study of sub-population connectivity is now needed in this zone as well as an evaluation

540 of the hybrid index of these populations. Combining the use of a large number of SNP

541 markers and an experimental genomic approach with genetically-divergent populations

542 (e.g. MO and North Brittany populations) would provide some insight into the tolerance

543 to elevated temperatures of M. balthica in the context of global warming. 
546 Acknowledgements

547 This research was supported by the European Committee (Research Directorate

548 General, Environmental Program Marine Ecosystems) through the BIOCOMBE-project 549 (contrat EVK3-2001-00146) and the Agence Nationale de la Recherche (Hi-Flo project 550 ANR-08-BLAN-0334-01). A "Contrat de Projet Etat-Region" (CPER) covered the 551 salary of EP. The authors acknowledge the technical support provided by Mikael 552 Guichard, Marc-Henri Boisis-Delavaud and Frederic Bret from the IT Center at the

553 University of La Rochelle. The University of La Rochelle computing infrastructure 554 "YMIR" was partly funded by the European Union (contract 31031-2008, European 555 Regional Development Fund). We also wish to thank Sandra Kube, Jeroen Jansen and 556 Frederic Robin for help with fieldwork, and Alice Saunier for her help in the lab. 
References

559

560 Alleaume-Benharira, M., Pen, I.R., Ronce, O., 2006. Geographical patterns of adaptation within a species' range: interactions between drift and gene flow. J.

562 Evol. Biol. 19, 203-215.

563

Armsworth, P.R., James, M.K., Bode, L., 2001. When to Press On or Turn Back: Dispersal Strategies for Reef Fish Larvae. Am. Nat. 157, 434-450.

565

Austin, J.D., Lougheed, S.C., Boag, P.T., 2004. Discordant temporal and geographic patterns in maternal lineages of eastern North American frogs, Rana catesbeiana (Ranidae) and Pseudacris crucifer (Hylidae). Mol. Phylo. Evol. 32, 799-816.

Bachelet, G., 1980. Growth and recruitment of the tellinid bivalve Macoma balthica at the southern limit of its geographical distribution, the Gironde Estuary (SW France). Mar. Biol. 59, 105-117.

Bandelt, H.J., Forster, P., Rohl, A., 1999. Median-joining networks for inferring intraspecific phylogenies. Mol. Biol. Evol. 16, 37-48.

Barton, N.H., Hewitt, G.M., 1985. Analysis of Hybrid Zones. Annu. Rev. Ecol. Syst. $16,113-148$.

Belkhir, K., Borsa, P., Chikhi, P., Raufaste, N., Bonhomme, F., 1996-2004. GENETIX 4.05, logiciel sous windows pour la génétique des populations. Laboratoire Génome, Populations, Interactions, CNRS UMR 5000, Universités de Montpellier II, Montpellier, France.

Becquet, V., Lanneluc, I., Simon-Bouhet, B., Garcia, P., 2009. Microsatellite markers for the Baltic clam, Macoma balthica (Linné, 1758), a key species concerned by changing southern limit, in exploited littoral ecosystems. Cons. Genet. Res. 1, 265-269.

583 Bell, G., Collins, S., 2008. Adaptation, extinction and global change. Evol. Appl. 1, 3- 
16.

585 Beukema, J.J., De Vlas, J., 1989. Tidal-current transport of thread-drifting postlarval 586 juveniles of the bivalve Macoma balthica from the Wadden Sea to the North Sea. Mar. Ecol. Prog. Ser. 52, 193-200.

Bierne, N., David, P., Langlade, A., Bonhomme, F., 2002. Can habitat specialisation maintain a mosaic hybrid zone in marine bivalves? Mar. Ecol. Prog. Ser. 245,157170.

Bierne, N., Bonhomme, F., David, P., 2003a. Habitat preference and the marine592 speciation paradox. Proc. R. Soc. Lond. B. 270, 1399-1406.

Bierne, N., Borsa, P., Daguin, C., Jollivet, D., Viard, F., Bonhomme, F., David, P., 2003b. Introgression patterns in the mosaic hybrid zone between Mytilus edulis and M. galloprovincialis. Mol. Ecol. 12, 447-461.

Bolnick, D.I., Caldera, E.J., Matthews, B., 2008. Evidence for asymmetric migration load in a pair of ecologically divergent stickleback populations. Biol. J. Linn. Soc. 94, 273-287.

Boutier, B., Michel, P., Chiffoleau, J.F., Auger, D., Chartier, E., 2000. Variations des concentrations et des flux de cadmium dissous dans la Gironde, IFREMER.

Bouzat, J.L., Johnson, K., 2004. Genetic structure among closely spaced leks in a 602 peripheral population of lesser prairie-chickens. Mol. Ecol. 13, 499-505.

603

Brown, W.M., George, M., Wilson, A.C., 1979. Rapid evolution of animal mitochondrial DNA. Proc. Natl. Acad. Sci. 76, 1967-1971.

606

Brown, J.H., Mehlman, D.W., Stevens, G.C., 1995. Spatial variation in abundance. Ecology. 76, 2028-2043.

Caddy, J.F., 1967. Development of mantle organs, feding and locomotion in postlarval 608 Macoma balthica (L.) (Lamellibranchiata). Can. J. Zool. 47, 609-617.

609 Caley, M.J., Carr, M.H., Hixon, M.A., Hughes, T.P., Jones, G.P., Menge, B.A., 1996. 

Syst. 27, 477-500.

612 Camphuysen, C.J., Berrevoets, C.M., Cremers, H.J.W.M., Dekinga, A., Dekker, R., 613 Ens, B.J., Van der Have, T.M., Kats, R.K.H., Kuiken, T., Leopold, M.F., Van der 614 Meer, J., Piersma, T., 2002. Mass mortality of common eiders (Somateria 615 mollissima) in the Dutch Wadden Sea, winter 1999/2000: Starvation in a 616 commercially exploited wetland of international importance. Biol. Cons. 106, 303-317.

618 Cassens, I., Van Waerebeek, K., Best, P.B., Crespo, E.A., Reyes, J., Milinkovitch, 619 M.C., 2003. The phylogeography of dusky dolphins (Lagenorhynchus obscurus): 620 a critical examination of network methods and rooting procedures. Mol. Ecol. 12, 1781-1792.

622 Chen, C., Durand, E., Forbes, F., François, O., 2007. Bayesian clustering algorithms 623 ascertaining spatial population structure: a new computer program and a comparison study. Mol. Ecol. Resour. 7, 747-756.

Cornuet, J.M., Piry, S., Luikart, G., Estoup, A., Solignac, M., 1999. New methods employing multilocus genotypes to select or exclude populations as origins of individuals. Genetics. 153, 1989-2000.

Courchamp, P., Clutton-Brock, T., Grenfell, B., 1999. Inverse density dependence and the Allee effect. Trends. Ecol. Evol. 14, 405-410.

630 Cowen, R.K., Lwiza, K.M.M., Sponaugle, S., Paris, C.B., Olson, D.B., 2000. 631 Connectivity of marine populations: open or closed ? Science. 287, 857-859.

632 Cowen, R.K., Gawarkiewicz, G., Pineda, J., Thorrold, S.R., Werner, F.E., 2007. Population connectivity in marine system. Oceanography. 20, 14-21.

634 Cowen, R.K., Sponaugle, S., 2009. Larval dispersal and marine population connectivity. Annu. Rev. Marine. Sci. 1, 443-466. 
636 Crandall, K.A., Bininda-Emonds, O.R.P., Mace, G.M., Wayne, R.K., 2000. Considering 637 evolutionary processes in conservation biology. Trends. Ecol. Evol. 15, 290-295.

638 Drent, J., 2002. Temperature responses in larvae of Macoma balthica from a northerly 639 and southerly population of the European distribution range. J. Exp. Mar. Biol. $640 \quad$ Ecol. 275, 117-129.

641 Dulvy, N.K., Rogers, S.I., Jennings, S., Stelzenmüller, V., Dye, S.R., Skoldal, H.R., 642 2008. Climate change and deepening of the North Sea fish assemblage: a biotic 643 indicator of warming seas. J. Appl. Ecol. 45, 1029-1039.

644 Dupont, L., Jollivet, D., Viard, F., 2003. High genetic diversity and ephemeral drift 645 effects in a recent and successful introduced mollusc (Crepidula fornicata: 646 Gastropoda). Mar. Ecol. Prog. Ser. 253, 183-195.

647 Durand, E., Jay, F., Gaggiotti, O.E., François., O., 2009. Spatial inference of 648 admixture proportions and secondary contact zones, Mol. Biol. Evol. 26, 649 1963-1973.

650 Durka, W., 1999. Genetic diversity in peripheral and subcentral populations of 651 Corrigiola litoralis L. (Illecebracea). Heredity. 83, 476-484.

652 Eckert, C.G., Samis, K.E., Lougheed, S.C., 2008. Genetic variation across species' 653 geographical ranges: the central-marginal hypothesis and beyond. Mol. Ecol. 17, $1170-1188$.

Edjung, G., Bonsdorff, E., 1992. Predation on the bivalve Macoma balthica by the 656 isopod Saduria entomon : laboratory and field experiments. Mar. Ecol. Prog. Ser. $88,207-214$.

Ellien, C., Thiebaut, E., Barnay, A.S., Dauvin, J.C., Gentil, F., Salomon, J.C., 2000. The 659 influence of variability in larval dispersal on the dynamics of a marine metapopulation in the eastern Channel. Oceanol. Acta. 23, 423-442.

661 El Mousadik, A., Petit, R.J., 1996. High level of genetic differentiation for allelic 

endemic to Morocco. Theor. Appl. Genet. 92, 832-839.

664 Estoup, A., Angers, B., 1998. Microsatellites and minisatellites for molecular ecology: 665 theorical and empirical considerations. In: Advances in molecular ecology, pp 5586, NATO press, Amsterdam.

667 Excoffier, L., Smouse, P.E., Quattro, J.M., 1992. Analysis of molecular variance inferred from metric distances among DNA haplotypes: application to human mitochondrial DNA restriction data. Genetics. 131, 479-491.

Excoffier, L., Laval, G., Schneider, S., 2005. Arlequin (version 3.0): An integrated

Falush, D., Stephens, M., Pritchard, J.K., 2003. Inference of population structure using multilocus genotype data: linked loci and correlated allele frequencies. Genetics. $164,1567-1587$.

Falush, D., Stephens, M., Pritchard, J.K., 2007. Inference of population structure using

François, O., Durand, E., 2010. Spatially explicit Bayesian clustering models in 680 population genetics. Mol. Ecol. Resour. 10, 773-784. multilocus genotype data: dominant markers and null alleles. Mol. Ecol. Resour. $7,574-578$ .

GIEC, 2007. Bilan des changements climatiques: Contribution des groupes de travail I, II et III au quatrième rapport d'évaluation du Groupe d'Experts Intergouvernemental sur l'évolution du climat ( Equipe de rédaction principale : Pachauri R.K., Resinger A.) GIEC. Genève, Suisse. 103pp.

Gill, J.A., Langston, R.H.W., Alves, J.A., Atkinson, P.W., Bocher, P., Cidraes Vieira, N., Crockford, N.J., Gélinaud, G., Groen, N., Gunnarsson, T.G., Hayhow, B., Hooijmeijer, J., Kentie, R., Kleijn, D., Lourenço, P.M., Masero, J.A., Meunier, F., 

Piersma, T., 2007. Contrasting trends in two Black-tailed Godwit populations: a review of causes and recommendations. Wader Study Group Bull. 114, 43-50.

Goikoetxea, N., Borja, A., Fontán, A., González, M., Valencia, V., 2009. Trends and anomalies in sea-surface temperature, observed over the last 60 years, within the southeastern Bay of Biscay. Cont. Shelf. Res. 29, 1060-1069.

Gómez, A., Lunt, A.H., 2007. Refugia within refugia: patterns of phylogeographic 695 concordance in the Iberian Peninsula, in: Wein S., Ferrand N., (eds), Phylogeography of Southern European Refugia, 155-188.

697 Gordon, D.R., 1998. Effect of invasive, non-indigenous plant species on ecosystem 698 processes: lessons from Florida. Ecol. Appl. 8, 975-989.

Goudet, J., 2002 FSTAT version 2.9.3.2. Available from Jerome.goudet@ie.zea.unil.ch, 700 via email. Institute of Ecology, UNIL, CH-1015, Lausanne, Switzerland.

Grousset, F.E., Jouanneau, J.M., Castaing, P., Lavaux, G., Latouche, C., 1999. A 70 702 year Record of Contamination from Industrial Activity Along the Garonne River and its Tributaries (SW France). Estuar. Coast. Shelf. Sci. 48, 401-414.

Guillot, G., Estoup, A., Mortier, F., Cosson, J-F., 2005a. A spatial statistical model for landscape genetics. Genetics. 170, 1261-1280.

Guillot, G., Mortier, F., Estoup, F., 2005b. Geneland : a program for landscape genetics. Mol. Ecol. Notes. 5, 712-715.

Guillot, G., 2009. On the inference of spatial structure from population genetics data using the TESS program. Bioinformatics. 25, 1-7.

710 Guillot, G., Renaud, S., Ledevin, R., Michaux, J., Claude, J. , 2012. A Unifying Model for the Analysis of Phenotypic, Genetic and Geographic Data. Systematic Biology. In press.

713 Hall, T.A., 1999. BioEdit: a user-friendly biological sequence alignment editor and 
analysis program for Windows 95/98/NT. Nuc. Ac. Symp. Ser. 41, 95-98.

715 Hellberg, M.E., Burton, R.S., Neigel, J.E., Palumbi, S.R., 2002. Genetic assessment of 716 connectivity among marine populations. Bull. Mar. Sci. 70, 273-90.

717 Hewitt, G.M., 1999. Post-glacial re-colonization of European biota. Biol. J. Linn. Soc. $68,87-112$.

Howes, B.J., Lindsay, B., Lougheed, S.C., 2006. Phylogeography of a temperate lizard. Mol. Phylo. Evol. 40, 183-194.

721

722

723

724

Hubisz, M.J., Falush, D., Stephens, M., Pritchard, J.K., 2009. Inferring weak population structure with the assistance of sample group information. Mol. Ecol.Resour. 9, $1322-1332$.

Hugues, L., 2000. Biological consequences of global warming: is the signal already. Trends. Ecol. Evol. 15, 56-61.

Hummel, H., 1985. Food intake of Macoma balthica (Mollusca) in relation to seasonal changes in its potential food on a tidal flat in the Dutch Wadden Sea. Neth. J. Sea. Res. 19, 52-76.

Hummel, H., Bogaards, R.H., Amiard-Triquet, C., Bachelet, G., Desprez, M., Marchand, J., Rybarczyk, H., Sylvand, B., de Wit, Y., de Wolf, L., 1995. Uniform variation in genetic traits of a marine bivalve related to starvation, pollution and geographic clines. J. Exp. Mar. Biol. Ecol. 191, 133-150.

Hummel, H., Bogaards, R., Bek, T., Polishchuk, L., Amiard-Triquet, C., Bachelet, G., Desprez, M., Strelkov, P., Sukhotin, A., Naumov, A., Dahle, S., Denisenko, S., Gantsevich, M., Sokolov, K., de Wolf, L., 1997b. Sensitivity to stress in the bivalve Macoma balthica from the most northern (Arctic) to the most southern (French) populations populations: low sensitivity in Arctic populations because of genetic adaptations? Hydrobiologia. 355, 127-138.

Hummel, H., Bogaards, R., Bek, T., Polishchuk, L., Sokolov, K., Amiard-Triquet, C., 

Macoma balthica from its northern to its southern distribution limit: a discontinuity in North Europe because of genetic adaptations in Arctic populations? Comp. Biochem. Physiol. A. 120, 133-141.

Hummel, H., Bogaards, R.H., Bachelet, G., Caron, F., Sola, J.C., Amiard-Triquet, C., 2000. The respiratory performance and survival of the bivalve Macoma balthica (L.) at the southern limit of its distribution area: a translocation experiment. J. Exp. Mar. Biol. Ecol. 251, 85-102

Jansen, J.M., Pronker, A.E., Kube, S., Sokolowski, A., Sola, J.C., Marquiegui, M.A., Schiedek, D., Bonga, S.W., Wolowicz, M., Hummel, H., 2007. Geographic and seasonal patterns and limits on the adaptive response to temperature of European Mytilus spp. and Macoma balthica populations. Oecologia. 154, 23-34.

Jolly, M.T., Jollivet, D., Gentil, F., Thiebaut, E., Viard, F., 2005. Sharp genetic break 753 between Atlantic and English Channel populations of the polychaete Pectinaria koreni, along the North coast of France. Heredity. 94, 23-32.

Kingsford, M.J., Leis, J.M., Shanks, A., Lindeman, K.C., Morgan, S.G., Pineda, J., 2002. Sensory environments, larval abilities and local self-recruitment. Bull. Mar. Sci. $70,309-40$

Koutsikopoulos, C., Beillois, P., Leroy, C., Taillefer, F., 1998. Temporal trends and 759 spatial structures of the sea surface temperature in the Bay of Biscay. Oceanol. Acta. 21, 335-344.

Lande, R., Engen, S., Sæther, B.E., 2003. Stochastic population dynamics in ecology and conservation. Oxford University Press, New York.

Lawton, J.H., 1993. Range, population abundance and conservation. Trends. Ecol. Evol. 8, 409-413.

765 Lazure, P., Jegou, A.M., 1998. 3D modelling of seasonal evolution of Loire and 
767 Lemaire, C., Versini, J.J., Bonhomme, F., 2005. Maintenance of genetic differentiation

768

769

770

771

772

773

774

775

776

777

778

779

780

781

782

783

784

785

786

787

788

789

790

791 across a transition zone in the sea: discordance between nuclear and cytoplasmic markers. J. Evol. Biol. 18, 70-80.

Leppäkoski, E., Gollasch, S., Olenin, S., 2002. (Eds.), Invasive aquatic species of Europe distribution, impacts and management. Hardcover, p600.

Librado, P., Rozas, J., 2009. DNAsp v5: a software for comprehensive analysis of DNA polymorphism data. Bioinformatics. 25, 1451-1452.

Luttikhuisen, P.C., Drent, J., Baker, A.J., 2003. Disjunct distribution of highly diverged mitochondrial lineage clade and population subdivision in a marine bivalve with pelagic larval dispersal. Mol. Ecol. 12, 2215-2229.

Maggs, C.A., Castilho, R., Foltz, D., Henzler, C., Taimour Jolly, M., Kelly, J., Olsen, J., Perez, K., Stam, W., Väinöla, R., Viard, F., Wares, J., 2008. Evaluating signatures of glacial refugia for North Atlantic benthic marine taxa. Ecology. 89, 108-122.

Mattila, J., Bonsdorff, E., 1998. Predation by juvenile flounder (Platichthys flesus L.): a test of prey vulnerability, predator preference, switching behaviour and functional response. J. Exp. Mar. Biol. Ecol. 227, 221-236.

Meekan, M.G., Carleton, J.H., McKinnon, A.D., Flynn, K., Furnas, M., 2003. What determines the growth of tropical reef fish larvae in the plankton: food or temperature? Mar. Ecol. Prog. Ser. 256, 193-204.

Moritz, C., 1994. Defining 'Evolutionarily Significant Units' for conservation. Trends Ecol. Evol. 9, 373-375.

Munday, P.L., Jones, G.P., Prachett, M.S., Williams, A.J., 2008. Climate change and the future for coral reef fishes. Fish. Fish. 9, 1-25.

Nei, M., 1987. Molecular evolutionnary genetics. Columbia University Press, NewYork. 
Nikula, R., Strelkov, P., Väinölä, R., 2007. Diversity and trans-arctic invasion history of mitochondrial lineages in the North Atlantic Macoma balthica complex (Bivalvia: Tellinidae). Evolution. 61, 928-941.

Nikula, R., Strelkov, P., Väinölä, R., 2008. A broad transition zonebetween an inner Baltic hybrid swarm and a pure North Sea subspecies of Macoma balthica (Mollusca, Bivalvia). Mol. Ecol. 17, 1505-1522.

O’Connor, M.I., Bruno, J.F., Gaines, S.D., Halpern, B.S., Lester, S.E., et al., 2007. Temperature control of larval dispersal and the implication for marine ecology, evolution and conservation. Proc. Natl. Acad. Sci. 104, 1266-1271.

Otero, J.H., Milan, F.J., 1970. Distribución de los moluscos: gasteropodos y pelecipodos, marinos, de las costas de Galicia. Cuad. Biol. 1, 79-93.

Parmesan, C., Yohe, G., 2003. A globally coherent fingerprint of climate change impacts across natural systems. Nature. 421, 37-42.

Pempkowiak, J., Szefer, P., 1992. Origin, sources and concentrations of selected heavy metals in the southern Baltic biota. Bulletin of the Sea, Rybackiego Institute. 125, 29-32.

Pempkowiak, J., Sikora, A., Biernacka, E., 1999. Speciation of heavy metals in marine sediments vs their bioaccumulation by mussels. Chemosphere. 39, 313-321.

Petit, R.J., Aguinagalde, I., De Beaulieu, J.L., Bittkau, C., Brewer, S., Cheddadi, R., Ennos, R., Fineschi, S., Grivet, D., Lascoux, M., Mohanty, A., Müller-Starck, G., Demesure-Musch, B., Palmé, A., Martín, J.P., Rendell, S., Vendramin, G.G., 2003. Glacial refugia: hotspots but not melting pots of genetic diversity. Science. $300,1563-1565$.

Philippart, C., Van Aken, H.M., Beukema, J.J., Bos, O.G., Cadee, G.C., Dekker, R., 2003. Climate-related changes in recruitment of the bivalve Macoma balthica. Limnol Oceanogr. 48, 2171-2185. 
818 Piersma, T., Beukema, J.J., 1993. Tropic interactions between shorebirds and their

819 invertebrate prey. Neth. J. Sea. Res. 31, 299-512.

820 Piry, S., Alapetite, A., Cornuet, J.M., Paetkau, D., Baudouin, L., Estoup, A., 2004.

821 GeneClass2: A software for genetic assignment and first-generation migrant 822 detection. J. Hered. 95, 536-539.

823 Pritchard, J., Stephens, M., Donnelly, P., 2000. Inference of population structure using 824 multilocus genotype data. Genetics. 155, 945-959.

825 R Development Core Team., 2010. R: A language and environment for statistical computing. R Foundation for Statistical Computing, Vienna, Austria. ISBN 3900051-07-0, URL http://www.R-project.org.

Rannala, B., Mountain, J.L., 1997. Detecting immigration by using multilocus genotypes. Proc. Nat. Am. Soc. 94, 9197-9201.

RNO (Réseau National d'Observation) 2004b. Résultats de la surveillance de la qualité du milieu marin littoral, Départements: Gironde, Landes, Pyrénées Atlantiques. Ifremer-Station de Nantes 115pp.

(available at: http://www.ifremer.fr/envlit/pdf/surveillancepdf/bull2004/bul_ar_2004.pdf).

834 Ronce, O., Kirckpatrick, M., 2001. When sources become sinks : migrational meltdown in heterogeneous habitats. Evolution. 55, 1520-1531.

Rousset, F., 2008. GENEPOP'007: a complete re-implementation of the GENEPOP software for Windows and Linux. Mol. Ecol. Res. 8, 103-106.

Scarlatto, O.A., 1981. The bivalve molluscs of the boreal Western Pacific. Nauka, Leningrad.

840 Schroter, D., Cramer, W., Leemans, R., Prentice, I.C., Araújo, M.B., Arnell, N.W., Bondeau, A., Bugmann, H., Carter, T.R., Gracia, C.A., De la Vega-Leinert, A.C., Erhard, M., Ewert, F., Glendining, M., House, J.I., Kankaanpää, S., Klein, R.J.T., Lavorel, S., Lindner, M., Metzger, M.J., Meyer, J., Mitchell, T.D., Reginster, I., 

Thonicke, K., Thuiller, W., Tuck, G., Zaehle, S., Zierl, B., 2005. Ecosystem service supply and vulnerability to global change in Europe. Science. 310, 13331337.

Shanks, A.L., Grantham, B.A., Carr, M.H., 2003. Propagule dispersal and the size and spacing of marine reserves. Ecol. Appl. 13, 159-69.

Siegel, D.A., Kinlan, B.P., Gaylord, B., Gaines, S.D., 2003. Lagrangian descriptions of 851 marine larval dispersion. Mar.Ecol. Prog. Ser. 260, 83-96.

Strelkov, P., Nikula, R., Väinölä, R., 2007. Macoma balthica in the White and Barents Seas: properties of a widespread marine hybrid swarm (Mollusca: Bivalvia). Mol. Ecol. 16, 4110-4127.

Swearer, S.E., Shima, J.S., Hellberg, M.E., Thorrold, S.R., Jones, G.P., Robertson, D.R., Morgan, S.G., Selkoe, K.A., Ruiz, G.M., Warner, R.R., 2002. Evidence of self-recruitment in demersal marine populations. B. Mar. Sci. 70, 251-271.

Szaniawska, A., Janas, U., Normant, M., 1996 Changes in macrozoobenthos communities induced by anthropogenic eutrophication of the Gulf of Gdansk, in: Gray J.S., et al., (eds), Biogeochemical Cycling and Sediment Ecology. 147-152 .

Szefer, P., Skwarzec, B., 1988. Distribution and possible sources of some elements in the sediment cores of the Southern Baltic. Mar. Chem. 23, 109-129.

Tajima, F., 1989. Statistical method for testing the neutral mutation hypothesis by DNA polymorphism. Genetics. 123, 585-595.

865 Thomas, C.D., Kunin, W.E., 1999. The spatial structure of populations. J. Anim. Ecol. $68,647-657$.

867 Thompson, J.D., Higgins, D.G., Gibson, T.J., 1994. CLUSTAL W: improving the 868 sensitivity of progressive multiple sequence alignment through sequence weighting, position-specific gap penalties and weight matrix choice. Nuc. Ac. 
871 Toonen, R.J., Tyre, A.J., 2007. If larvae were smart: a simple model for optimal settlement behavior of competent larvae. Mar. Ecol. Prog. Ser. 349, 43-61.

873 Väinölä, R., 2003. Repeated trans-Arctic invasions in littoral bivalves: molecular zoogeography of the Macoma balthica complex. Mar. Biol. 143, 935-946.

Vitousek, P., Mooney, H., Lubchenco, J., Mellilo, J., 1997. Human domination of Earth's ecosystems. Sciences. 277, 494-499.

Vucetich, J.A., Waite, T.A., 2003. Spatial patterns of demgraphy and genetic processes across the species' range: null hypotheses for landscape conservation genetics. Cons. Gen. 4, 639-645.

Walker, D., Kendrick, G., 1998. Threats to macroalgual diversity: marine habitat destruction and fragmentation, pollution and introduced species. Bot. Mar. 41, 105-112.

Walther, G.R., Post, E., Convey, P., Menzel, A., Parmesan, C., Beebee, T.J.C., 884 Fromentin, J.M., Hoegh-Guldberg, O., Bairlein, F., 2002. Ecological responses to recent climate change. Nature. 416, 389-395.

Wethey, D.S., Woodin, S.A., 2008. Ecological hindcasting of biogeographic responses 887 to climate change in the European intertidal zone. Hydrobiologia. 606, 139-151.

Wilding, C.S., Beaumont, A.R., Latchford, J.W., 1997. Mitochondrial DNA variation in the scallop Pecten maximus (L.) assessed by a PCR-RFLP method. Heredity. 79, 178-189.

891 Wright, S., 1951. The genetical structure of populations. Ann. Eugen. 15, 323-354.

892 Zouros, E., Foltz, D.W., 1984. Possible explanation of heterozygote deficiency in 893 bivalve molluscs. Malacologia. 25, 583-592.

894 Zwarts, L., Blomert, A.M., 1992. Why knot Calidris canutus take medium-sized 895 Macoma balthica when six prey species are available. Mar. Ecol. Prog. Ser. 83, 
113-128.

897 


\begin{tabular}{|c|c|c|c|c|c|}
\hline Sampling Site & Code & Latitude (N) & Longitude (W) & $\mathrm{N}_{\text {mito }}$ & $\mathrm{N}_{\text {nuc }}$ \\
\hline (1) Bonne Anse & $\mathrm{BON}$ & 45.5523 & -0.9294 & 16 & 13 \\
\hline (2) Charente & $\mathrm{CHA}$ & 45.9583 & -1.0501 & 15 & 25 \\
\hline (3) Fouras & $\mathrm{F}$ & 45.984 & -1.0925 & 8 & 36 \\
\hline (4) Yves & $\mathrm{Y}$ & 46.0116 & -1.0561 & 0 & 39 \\
\hline (5) Aytre & AY & 46.126 & -1.1306 & 13 & 50 \\
\hline (6) Aiguillon & AIG & 46.1617 & -1.1298 & 31 & 16 \\
\hline (7) Noirmoutiers & NM & 46.9035 & -2.1671 & 20 & 40 \\
\hline (8) Loire & LOI & 47.2675 & -2.1715 & 24 & 47 \\
\hline (9) Pont-Mahe & PT-MH & 47.4442 & -2.4608 & 16 & 23 \\
\hline (10) Mont Saint Michel & MSM & 48.438 & -1.5153 & 30 & 30 \\
\hline (11) Seine & SEI & 49.4029 & 0.1205 & 32 & 29 \\
\hline (12) Somme & $\mathrm{SOM}$ & 50.2146 & 1.6227 & 29 & 28 \\
\hline (13) Westerschelde & WES & 51.3792 & 3.6272 & 31 & 27 \\
\hline (14) Balgzand & WAD & 52.9301 & 4.7953 & 31 & 28 \\
\hline (15) Wilhemshaven & WIL & 53.4802 & 8.0641 & 32 & 28 \\
\hline (16) Sylt & SYL & 54.7789 & 8.2954 & 40 & 40 \\
\hline (17) Ireland & IRE & 53.257 & -9.1201 & 36 & 31 \\
\hline (18) Murman & MUR & 69.3073 & 33.556 & 20 & 15 \\
\hline
\end{tabular}

Table 1: Sampling sites, locality codes, GPS coordinates (WGS84) and number of individuals analysed with mitochondrial $\left(\mathrm{N}_{\text {mito }}\right)$ and microsatellites nuclear markers $\left(\mathrm{N}_{\mathrm{nuc}}\right)$ for the eighteen European sampling sites of Macoma balthica. 
Mitochondrial data

Nuclear data

\begin{tabular}{|c|c|c|c|c|c|c|c|c|c|c|c|c|}
\hline Bay of Biscay & $\mathbf{N}$ & $\mathbf{S}$ & $\mathbf{H}$ & Hd & $\pi$ & D & $\mathbf{N}$ & Nall & Rall & Ho & Hs & $F_{\text {IS }}$ \\
\hline (1) & 16 & 4 & 4 & 0.442 & 0.00269 & -0.792 & 13 & 6.625 & 4.3806 & 0.304 & 0.577 & 0.5027 \\
\hline (2) & 15 & 3 & 5 & 0.476 & 0.00188 & -0.513 & 25 & 8.526 & 4.5149 & 0.368 & 0.630 & 0.4325 \\
\hline (3) & - & - & - & - & - & - & 39 & 11 & 4.7357 & 0.375 & 0.661 & 0.4437 \\
\hline (4) & 8 & 2 & 2 & 0.536 & 0.05357 & 1.448 & 36 & 1.75 & 4.6560 & 0.368 & 0.640 & 0.4342 \\
\hline (5) & 13 & 7 & 5 & 0.628 & 0.07179 & -1.378 & 50 & 11.25 & 4.7440 & 0.434 & 0.659 & 0.3339 \\
\hline (6) & 31 & 4 & 5 & 0.434 & 0.00219 & -0.686 & 16 & 9.625 & 4.7716 & 0.408 & 0.670 & 0.4207 \\
\hline (7) & 20 & 2 & 3 & 0.468 & 0.04184 & 1.136 & 37 & 9.125 & 4.4706 & 0.430 & 0.676 & 0.3764 \\
\hline (8) & 24 & 5 & 5 & 0.493 & 0.03913 & -1.204 & 47 & 10.25 & 4.5025 & 0.381 & 0.674 & 0.4444 \\
\hline (9) & 16 & 2 & 3 & 0.508 & 0.03917 & 0.767 & 23 & 7.375 & 4.4446 & 0.423 & 0.654 & 0.3794 \\
\hline Total & 143 & 11 & 11 & 0.464 & 0.0411 & - & 286 & 18.25 & 4.5800 & 0.395 & 0.668 & 0.4305 \\
\hline Mean & 17.9 & 3.63 & 4 & 0.498 & 0.0315 & - & 31.78 & 8.392 & 4.5801 & 0.388 & 0.649 & 0.4186 \\
\hline (S.D.) & 7.08 & 1.768 & 1.195 & 0.062 & 0.0265 & - & 13.16 & 2.932 & 0.1475 & 0.041 & 0.031 & 0.0491 \\
\hline Core populations & $\mathbf{N}$ & $\mathbf{S}$ & $\mathbf{H}$ & Hd & $\pi$ & D & $\mathbf{N}$ & Nall & Rall & Но & Hs & $F_{\text {IS }}$ \\
\hline (10) & 30 & 4 & 2 & 0.129 & 0.00154 & -1.258 & 30 & 8.375 & 4.2451 & 0.376 & 0.618 & 0.4087 \\
\hline (11) & 32 & 4 & 3 & 0.123 & 0.00127 & -1.443 & 29 & 8.125 & 4.0295 & 0.333 & 0.599 & 0.4598 \\
\hline (12) & 29 & 4 & 3 & 0.490 & 0.00441 & 1.156 & 28 & 8.375 & 4.2860 & 0.329 & 0.602 & 0.4681 \\
\hline (13) & 31 & 5 & 4 & 0.385 & 0.00290 & -0.613 & 27 & 8.125 & 4.3306 & 0.303 & 0.626 & 0.5298 \\
\hline (14) & 31 & 3 & 2 & 0.512 & 0.00460 & $2.436^{*}$ & 28 & 8.750 & 4.3304 & 0.357 & 0.639 & 0.4570 \\
\hline (15) & 32 & 6 & 5 & 0.565 & 0.00491 & 0.281 & 28 & 8.125 & 4.2112 & 0.382 & 0.607 & 0.3864 \\
\hline (16) & 40 & 4 & 3 & 0.497 & 0.00448 & 1.414 & 40 & 9.500 & 4.2814 & 0.343 & 0.622 & 0.4613 \\
\hline (17) & 36 & 4 & 2 & 0.056 & 0.00067 & -1.88 & 31 & 7.625 & 4.1177 & 0.379 & 0.558 & 0.3354 \\
\hline (18) & 20 & 0 & 1 & 0 & 0 & - & 15 & 7.750 & 4.0522 & 0.293 & 0.673 & 0.3681 \\
\hline Total & 281 & 11 & 10 & 0.523 & 0.07684 & - & 256 & 15.50 & 4.2110 & 0.358 & 0.628 & 0.4434 \\
\hline Mean & 31.2 & 3.78 & 2.78 & 0.306 & 0.00275 & - & 28.44 & 8.306 & 4.2093 & 0.344 & 0.616 & 0.4305 \\
\hline (S.D.) & 5.40 & 1.64 & 1.20 & 0.225 & 0.00192 & - & 6.386 & 0.559 & 0.1157 & 0.033 & 0.031 & 0.0604 \\
\hline All populations & $\mathbf{N}$ & $\mathbf{S}$ & $\mathbf{H}$ & Hd & $\pi$ & D & $\mathbf{N}$ & Nall & Rall & Ho & Hs & $F_{\text {IS }}$ \\
\hline Total & 424 & 18 & 19 & 0.720 & 0.08984 & - & 542 & 20.875 & - & 0.3740 & 0.6500 & 0.4426 \\
\hline Mean & 24.9 & 3.71 & 3.35 & 0.396 & 0.01630 & - & 30.11 & 8.305 & 4.395 & 0.3660 & 0.6325 & 0.4246 \\
\hline (S.D.) & 9.15 & 1.65 & 1.32 & 0.192 & 0.02300 & - & 10.18 & 0.165 & 0.230 & 0.0425 & 0.0347 & 0.0537 \\
\hline
\end{tabular}

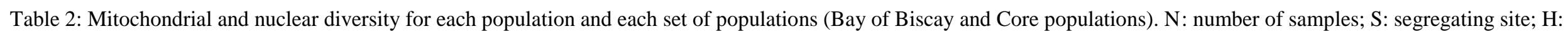

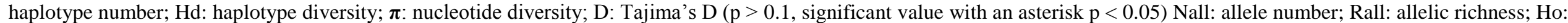
observed heterozygosity; Hs: gene diversity and $F_{\text {IS }}$ : heterozygote deficiency. 


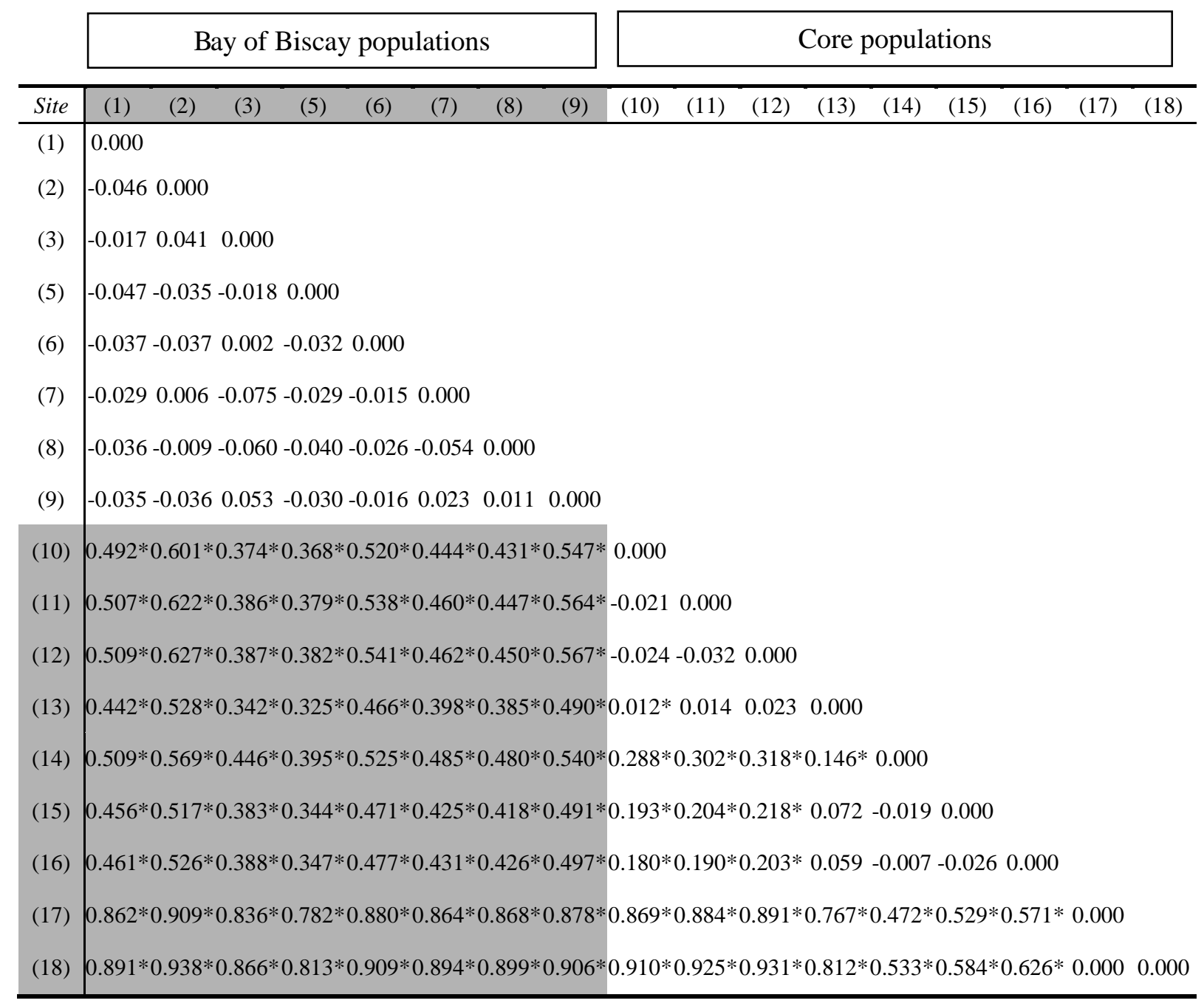

Table 3: Pairwise differentiation (mtDNA sequences).

Significant values are indicated with an asterisk (exact test, $\mathrm{p}<0.05$ ). 
Fig. 1: Sample sites and haplotype distribution for Macoma balthica populations. The colors used in pie charts are the same as in Fig. 2.

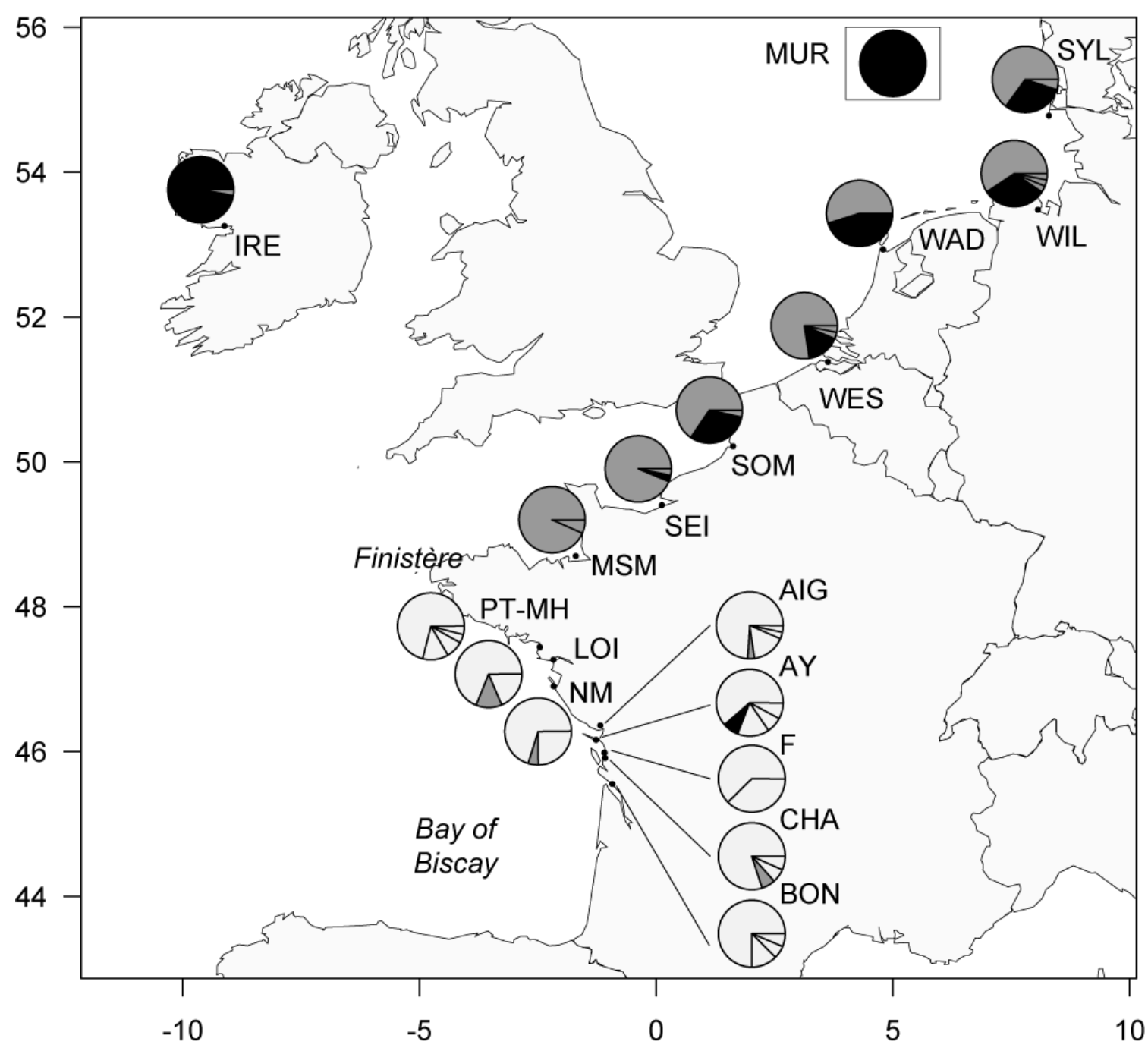


Fig. 2: Minimum spanning network displaying mitochondrial variation along $313 \mathrm{bp}$ of the COI gene. Each circle represents a haplotype. Circle size is proportional to haplotype frequency. Each segment represents a single mutational event. $\mathrm{H} 1$ and $\mathrm{H} 2$ are haplotypes typical of the Bay of Biscay, and $\mathrm{H} 3$ and $\mathrm{H} 4$ are characteristic of the Core populations.

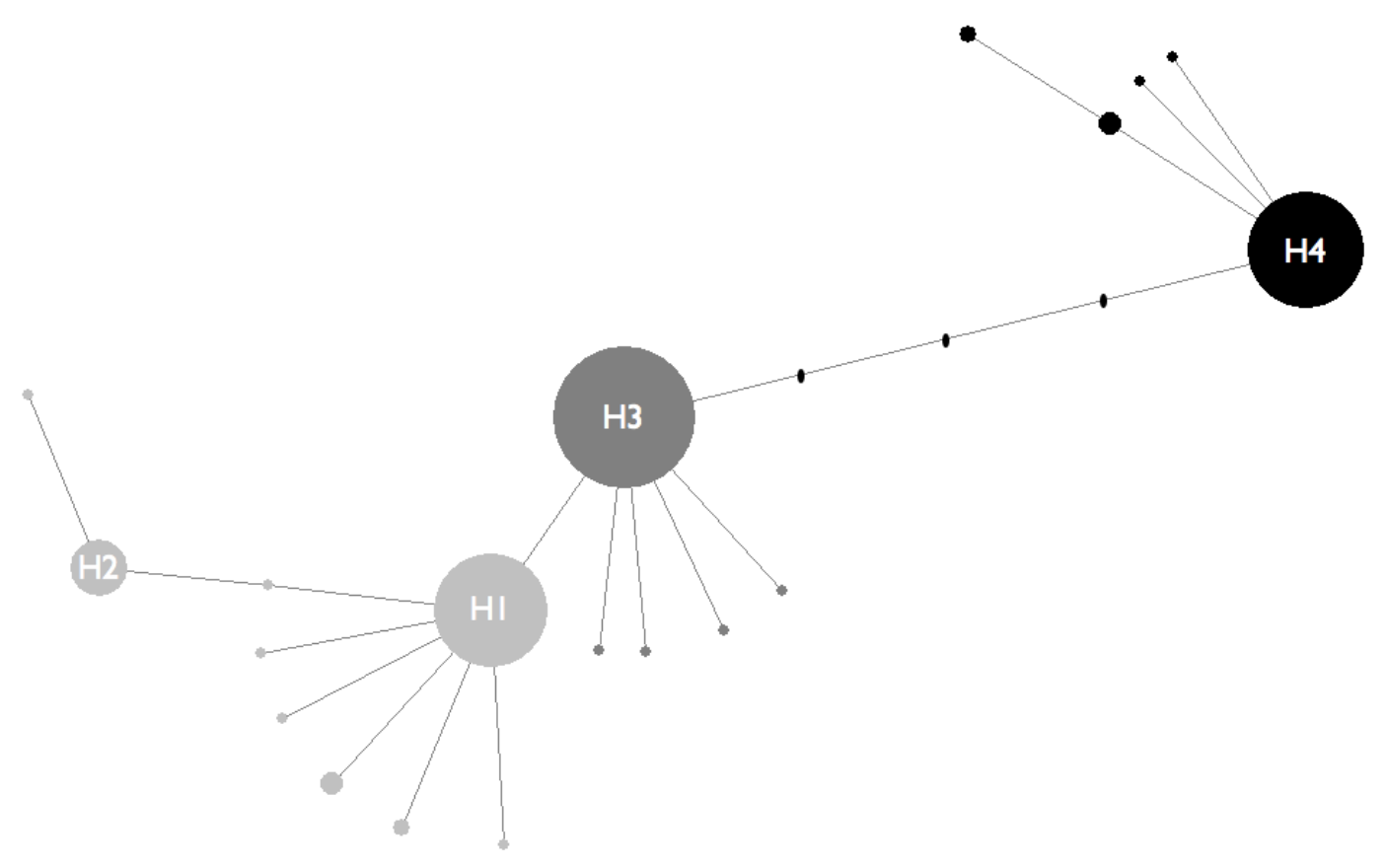


Fig. 3: Frequencies of the four most common haplotypes (H1-H4) identified along the European coast. Except for Ireland, sampling sites are ordered by increasing latitude along the $\mathrm{x}$-axis.

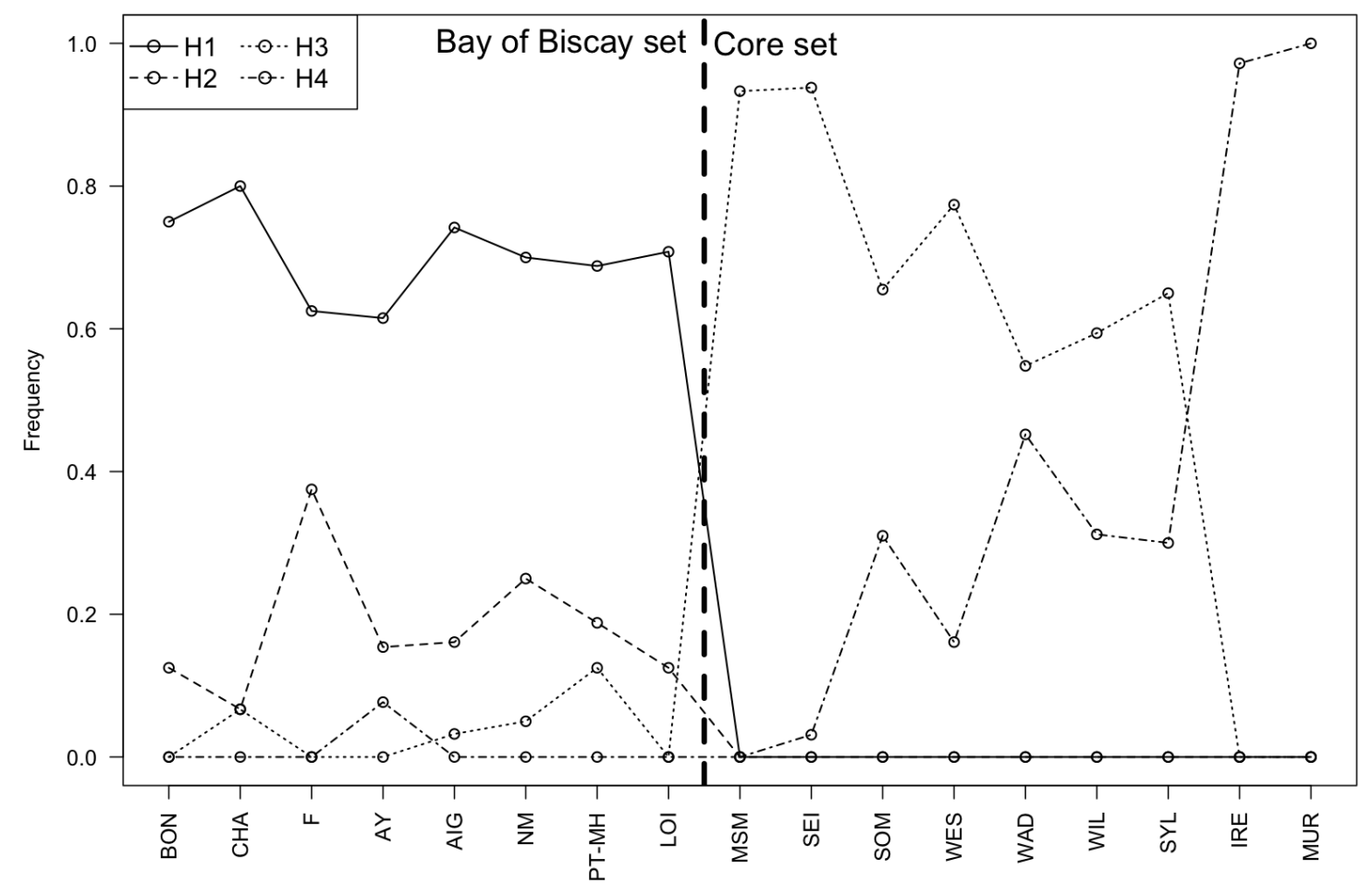


Fig. 4: Assignation proportions inferred by Geneclass. For each population presented in a column, the proportion of individuals assigned to populations on the right is represented by a square (scale: bottom left). For instance, most individuals sampled from Aytré were assigned to that same population (i.e., strong proportion of auto-assignation) and a few individuals only were assigned to the populations Y, CHA, LOI and MSM.

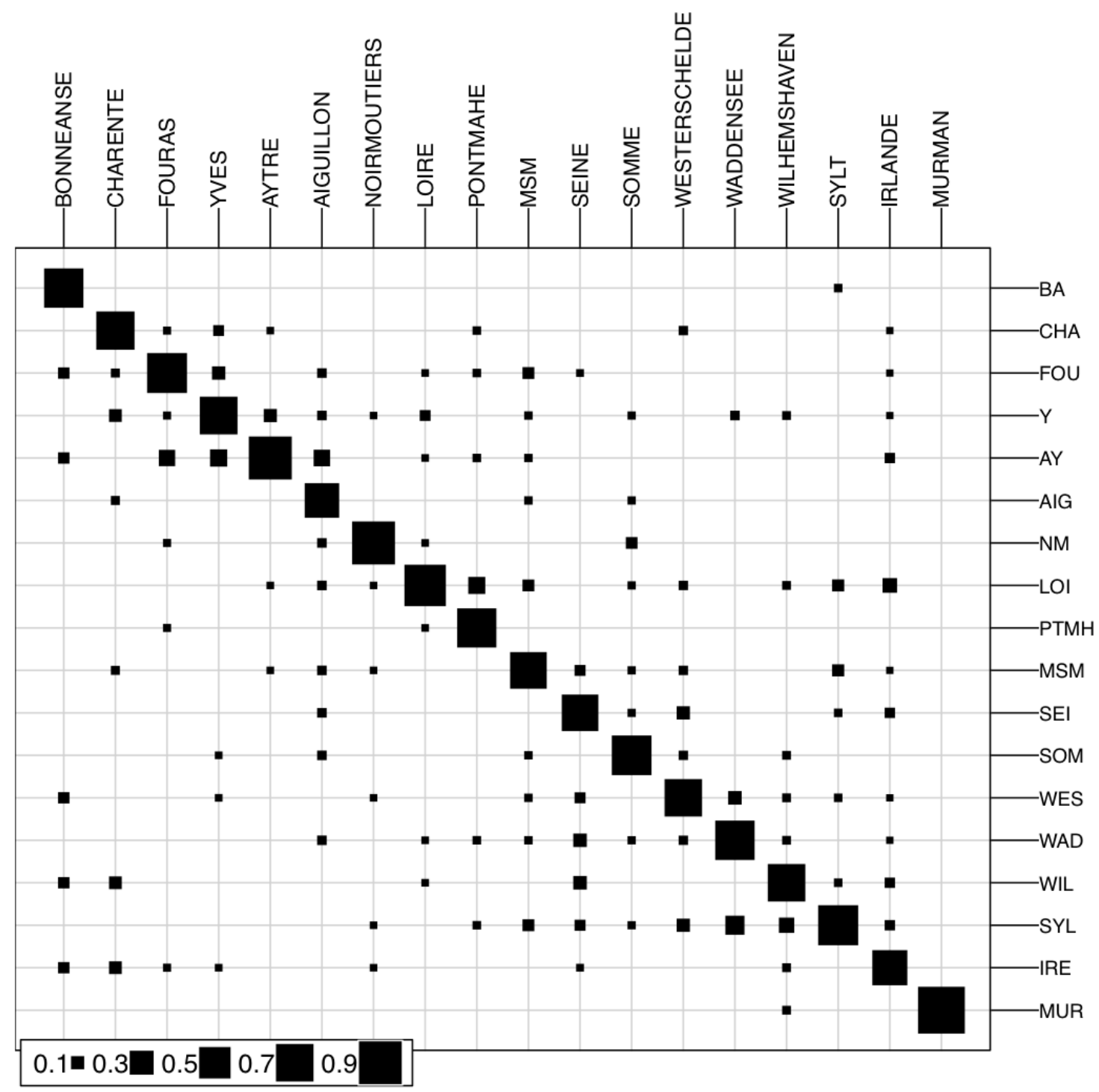


Fig. 5: Summary of spatial population clustering, based on results from Geneland, TESS and Structure analyses using mitochondrial and microsatellite dataset. At each sampling location, results from each program are given as a symbol, along a segment (see key). Filled circles represent nuclear data, while diamonds represent mitochondrial data. Symbol color represents cluster identity. Abbreviations: $\mathrm{mG}$, Geneland, mitochondrial data; $\mathrm{G}$, Geneland, nuclear data; T, TESS, nuclear data; S, Structure, nuclear data.

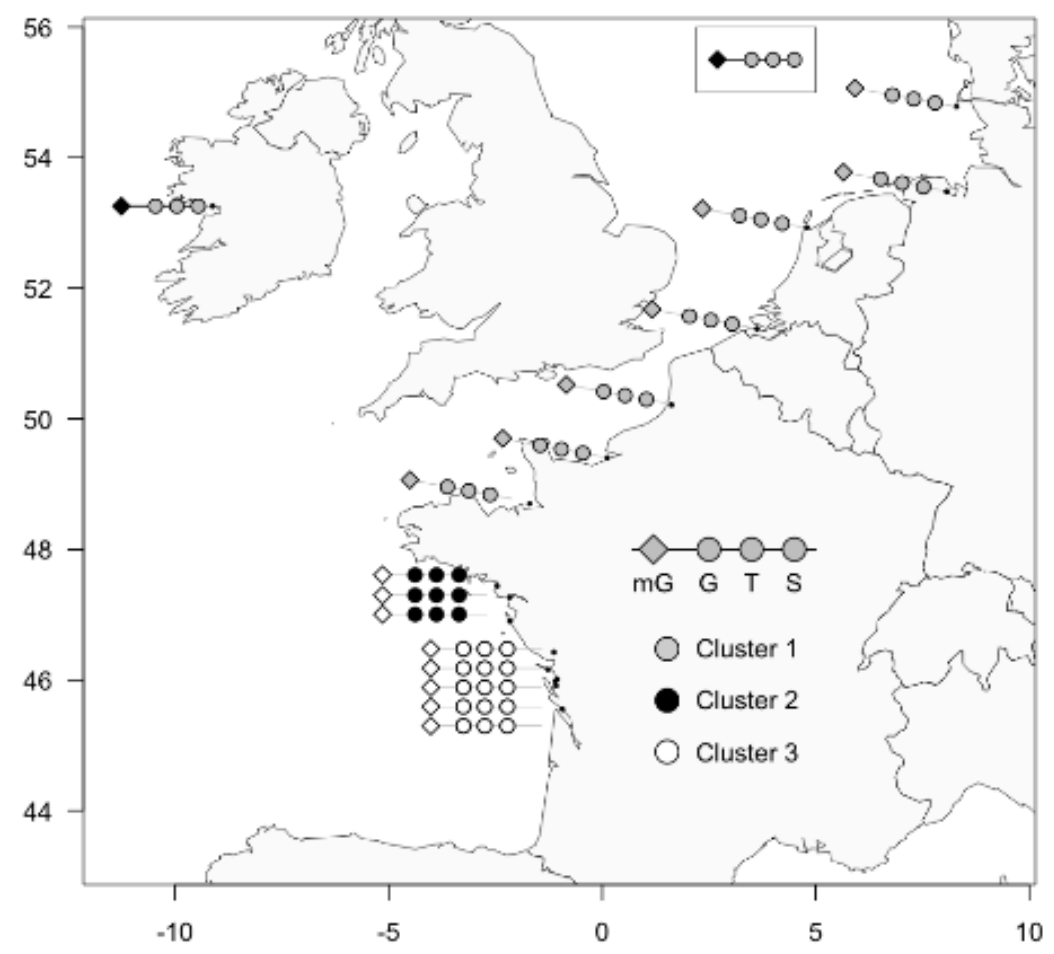


Fig. 6: Box-and-whisker plots of allelic richness in the Bay of Biscay and Core population sets. For each population set, the $\mathrm{R}_{\text {all }}$ values presented are (in order of decreasing values): maximum, third quartile, median, first quartile and minimum.

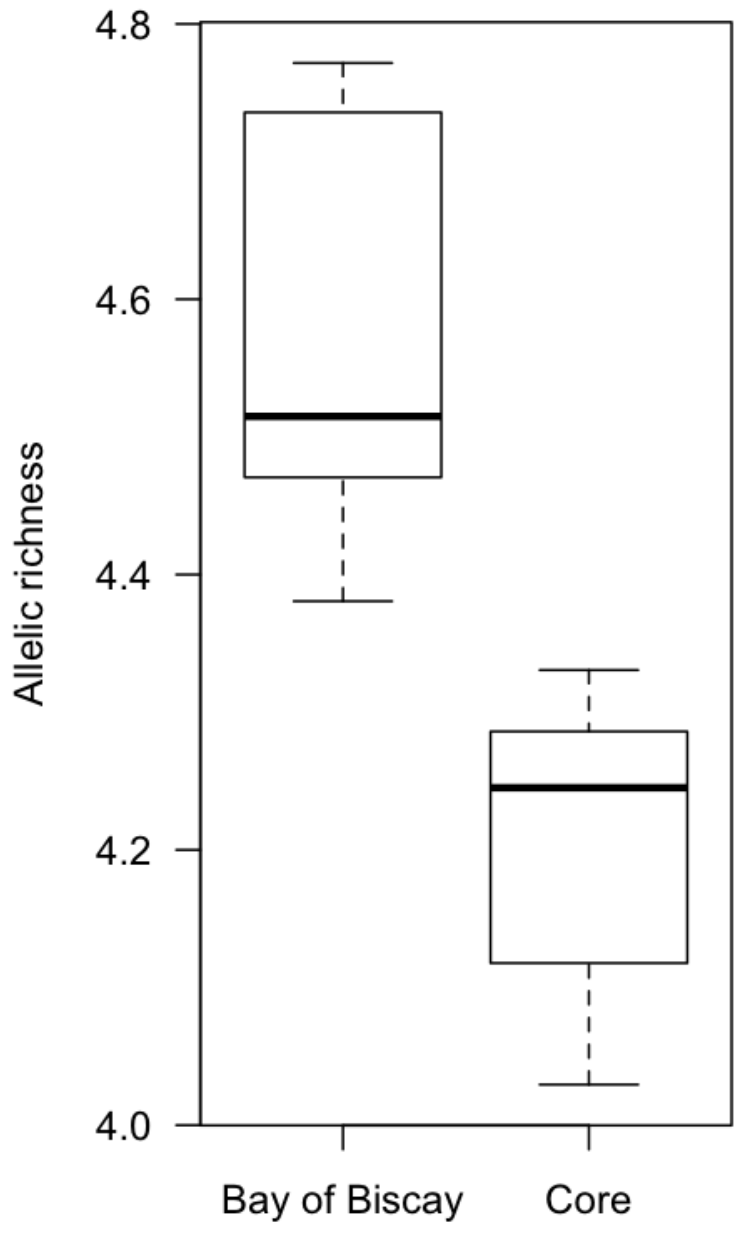


Fig. 7: Box-and-whisker plots of observed (white) and expected (grey) heterozygoties in the Bay of Biscay and Core populations sets.

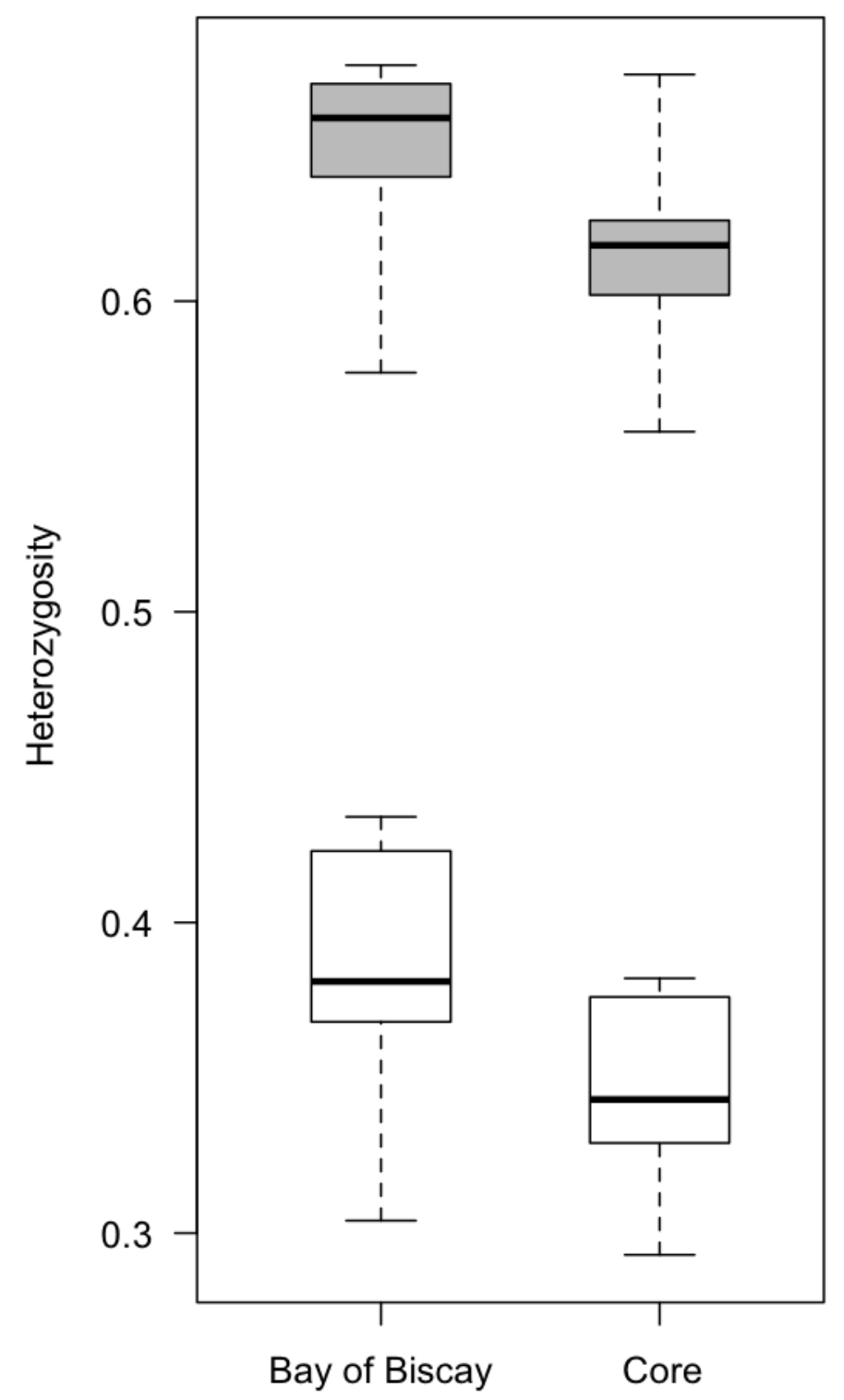

